\title{
MANAGING SPILLOVERS: AN ENDOGENOUS SUNK COST APPROACH
}

\author{
Olena Senyuta \\ Krešimir Žigić
}
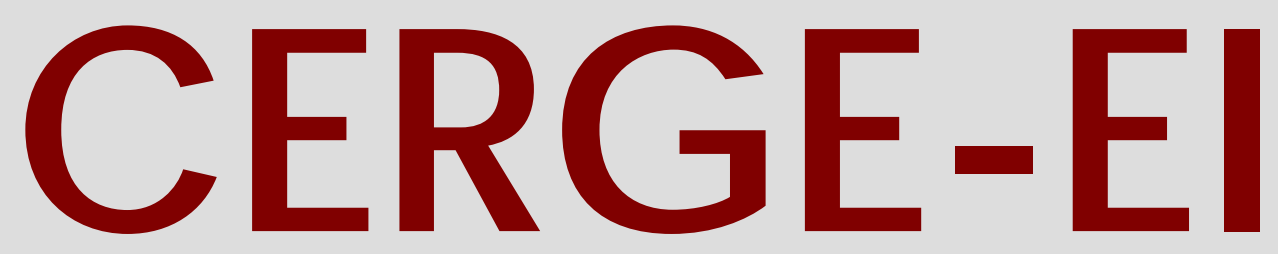

Cha rles University CenterforEconomic Research and Graduate Education Academy of Sciences of the Czech Republic Ec onomic s Institute 


\section{Working Paper Series $\mathbf{4 7 2}$ (ISSN 1211-3298)}

\section{Managing Spillovers: \\ An Endogenous Sunk Cost Approach}

Olena Senyuta

Krešimir Žigić

CERGE-EI

Prague, November 2012 
ISBN 978-80-7343-276-8 (Univerzita Karlova. Centrum pro ekonomický výzkum a doktorské studium)

ISBN 978-80-7344-268-2 (Národohospodářský ústav AV ČR, v.v.i.) 


\title{
Managing Spillovers: An Endogenous Sunk Cost Approach*
}

\author{
Olena Senyuta Krešimir Žigić \\ CERGE-EI ${ }^{\dagger}$
}

November 26, 2012

\begin{abstract}
We introduce spillover effect into John Sutton's $(1991,1998)$ concept of endogenous sunk costs. These sunk costs appear in the form of R\&D investment into quality in our framework. We show that with spillovers increasing and the effectiveness of investment in raising quality decreasing, the Sutton lower bound on concentration for an industry decreases and ultimately collapses to zero when spillovers are large enough and/or effectiveness of investment in raising quality is low enough.

In the second part, we allow firms to protect their investment against spillovers We focus on symmetric pure strategy Nash equilibria, where all firms either protect their investment or do not protect at all. Contrary to the result with exogenous spillovers assumed in the first part, in the second part of the paper we show that higher ex ante spillovers and/or lower effectiveness of investment in raising quality may induce firms to protect themselves against spillovers, leading to higher investment in quality, and to more concentrated market structure. Thus, the Sutton's result on the concentration bound is preserved, if we allow firms to manage spillovers via private protection.
\end{abstract}

JEL Classification: L13, O30

Keywords: endogenous sunk costs, knowledge spillovers, R\&D, innovations, market concentration

${ }^{*}$ This project was financially supported by grant number P402/12/0961 from the Grant Agency of the Czech Republic. We received a lot of beneficial "knowledge spillovers" from John Sutton, Avner Shaked, Jan Kmenta, Levent Celik, and Vilém Semerák. Also, this work was developed with institutional support RVO: 67985998.

${ }^{\dagger}$ CERGE-EI, a joint workplce of Charles Univesity and the Economics Institute of the Academy of Sciences of the Czech Republic, Politickych veznu 7, 11121 Prague, Czech Republic 


\begin{abstract}
Abstrakt
Zavádíme efekty přelévání do Suttonova konceptu endogenních utopených nákladů (Sutton 1991, 1998). Tyto utopené náklady se v našem modelu vyskytují ve formě investic do výzkumu a vývoje pro zvyšování kvality. Ukazujeme, že při zvyšujících se efektech přelévání a snižující se efektivitě investic do zvyšování kvality se Suttonova dolní mez koncentrace odvětví snižuje, přičemž klesá až k nule, pokud jsou efekty přelévání dostatečně významné a/nebo efektivita investování do zvyšování kvality dostatečně nízká.

Ve druhé části umožňujeme firmám své investice před efekty přelévání chránit. Zaměřujeme se na symetrické Nashovy rovnováhy v ryzích strategiích, kde všechny firmy bud' chrání svoje investice nebo je nechrání vůbec. Oproti výsledku s exogenními efekty přelévání předpokládanými v první části, ukazujeme ve druhé části článku, že vyšší ex ante efekty přelévání a/nebo nižší efektivita investic do zvyšování kvality může přimět firmy, aby se před efekty přelévání chránily, což vede k vyšším investicím do kvality a k vyšší koncentraci trhu. Suttonův výsledek ohledně meze koncentrace je tedy zachován, pokud umožníme firmám ovládat efekty přelévání prostřednictvím soukromé ochrany.
\end{abstract}




\section{Introduction}

In his influential book, John Sutton (1991) provides us with the theory that explains why some markets remain highly concentrated. His theory predicts that in the presence of a certain type of sunk costs there is lower bound on the level of concentration in an industry. More precisely, the number of firms in a free entry equilibrium would reach some finite number, even if the size of the market approaches infinity. This special type of sunk costs that leads to such an outcome is coined "endogenous sunk costs". Sutton (1991) focuses on advertising outlays as the premier type of endogenous sunk costs, but any kind of cost-reducing investment, or investment into quality, can be considered as an endogenous sunk cost. To illustrate his idea, Sutton (1991) builds a specific model in the form of a three-stage game with the first stage capturing entry decision, the second stage introducing the idea of endogenous sunk cost that comes in the form of the investment in advertisement, while the final stage describes the competition in quantities. The key characteristic of an investment in endogenous sunk costs is that it positively affects the consumers' perception of a good's quality or of a good's importance, exclusivity or uniqueness ("Live on the Coke Side of Life"). This in turn results in developing habits for the consumption of a good in question for the existing consumers and would also attract new consumers to buy the product when the market size becomes bigger. Thus, if the market size increases, incumbent firms invest more in advertisement in order to keep the existing consumers and capture the new ones and so this escalation mechanism of endogenous sunk costs makes entry of outside firms not profitable (see also Sutton, 2007) and lies at the core of so called non-fragmented equilibrium: the expansion of the market size beyond a certain threshold does not result in larger number of firms, and so there is a limit on firms' entry, and consequently on the lower bound of market concentration.

We build a similar three-stage setup like Sutton, (1991) but we focus on the markets where the endogenous sunk costs stem from an investment in product quality improvement rather than advertisement. Moreover, we introduce the knowledge or R\&D spillovers stemming from firms' investment in product quality. A firm's effective quality of the good is influenced by both the firm's own investment in quality, and 
investment in quality by other firms. In other words, a firm's product quality is a sum of its own quality innovations, and some portion of quality innovations developed independently by other firms. Thus, spillovers are assumed to be mutual; each firm benefits from spillovers coming from the other firms ("receiving spillovers") but at the same time each firm involuntarily provides spillovers to all other firms in an industry ("giving away spillovers"). These features reflect the fact that innovations and imitations are complements and reinforce each other (see Shenkar, 2010) ${ }^{1}$.

In the basic version of our model, we treat $R \& D$ spillovers as exogenous to firms (captured by a single parameter) while in the second part of the paper, we allow for the possibility for firms to manage spillovers. By that we mean deliberate actions of the firms to constrain giving away spillovers and to prevent a leakage of its relevant knowledge to its competitors.

There are several aims of our analysis: i) first, we investigate the robustness of the lower bound on concentration in the above setup in which knowledge spillovers are exogenous, and study the impact of spillovers on the equilibrium values such as endogenous sunk costs or market concentration,then ii) we allow firms to manage spillovers on their own, and study how the levels of spillovers and the effectiveness of investment in quality improvement (captured by a single parameter) would affect a firm's decision to protect or not against the giving away spillovers. iii) In addition to that, we again analyze how the possibility to restrain the giving away spillovers affects the lower bound of concentration and the level of endogenous sunk costs iv). Finally, we also investigate how the level of effectiveness of investment in quality improvement affect the endogenous sunk costs and, consequently, the market concentration.

As for the empirical relevance of our setup, especially as the presence of spillovers is concerned, one of the stylized facts about R\&D investment (endogenous sunk costs in our case) is knowledge diffusion and imperfect appropriability of innovations. Reverseengineering $^{2}$, labor force flows and strategic alliances among firms, among others, may serve as examples of such mutual knowledge spillovers and the mode by which they

\footnotetext{
${ }^{1}$ Shenkar (2010) coins the firms that practice both imitation and innovations "imovators" and provides numerous examples of such practice. For instance, he pointed to the case of $\mathrm{P} \& \mathrm{G}$ that already exceeded its goal of having one-third of new product ideas coming from the outsides.

${ }^{2}$ Reverse-engineering is disassembling of the product to learn how it was built and how it works.
} 
can be practically realized in an industry (see Shenkar, 2010 for many examples of these kind of knowledge leakages).

Several empirical studies confirm that many industries are characterized by a quick leak of information and knowledge. For example, Caballero and Jaffe (1993), and Henderson and Cockburn (1996) use firm-level data and find significant knowledge spillovers in several industries.

Audretsch and Feldman (1996) interpret R\&D spillovers as knowledge externalities which arise from clustered geographical location of firms. According to the empirical model presented in their paper, innovations tend to cluster in geographical space, even after the model accounts for the clustered location of production units. Depending on the size of those spillovers, for some industries clustering innovations in geographical space is more beneficial than it is for others.

A paper by Ellison et al. (2010) attempt to answer the question of what drives the geographical concentration of industries. The authors use coagglomeration plantlevel data for manufacturing industries in the USA to assess the importance of three different theories in explaining geographical concentration. The theories tested are: (1) agglomeration saves transport costs by proximity to input suppliers or final consumers ("goods"), (2) agglomeration allows for labor market pooling ("people"), and (3) agglomeration facilitates intellectual spillovers ("ideas"). The authors find that coagglomeration patterns in the manufacturing industries support all three theories of geographic concentration. Moreover all three factors are roughly equal in economic significance. This provides the evidence that mutual knowledge spillovers are present in the industries, and producers take this fact into account (see also, Shenkar, 2010).

Another example of how spillovers might be realized in reality is through input suppliers. Consider the close relationship between an innovating firm and its suppliers. Such a vertical relationship may result in those suppliers becoming more qualified and hence more attractive as partners to an innovating firm's competitors, potentially enabling these competitors to free ride on the R\&D investments made by the innovating firm (Mesquita et al., 2008). In other words, all partners of the supplier may benefit from the supplier's learning in relation to a specific firm that initially invests 
in the improved product quality (due to say specialized inputs requirement). It is reasonable to expect that some (if not the majority) of those partners would be competitors in the final product market. Although the risk of such knowledge dispersion can be reduced by exclusive partnership arrangements, this may not be sufficient to prevent knowledge spillovers to competitors completely. Therefore, this mechanism describes the "vertical channel" of knowledge dispersion between firms (see Javorcik, 2004) that could later on evolve in the horizontally linked spillovers where each firm benefits from the spillovers of other firms.

As for the empirical evidence of how the firms manage spillovers, besides patents and copyrights, the firms may undertake costly private protection to reduce or eliminate spillovers if they find it optimal. In some cases, spillovers might be characterized as information leakage or imitations that are on the border of intellectual property rights (IPR) violations and cannot be effectively suppressed by the public IPR protection (patents or copyrights). In this case, private or technical IPR protection (see Scotchmer, 2004, chapter 7 or Střelický and Žigić, 2011) is a plausible interpretation of managing spillovers.

Thus, in such an enriched setup, the firms can now simultaneously choose both its protection against spillovers and sunk investment in quality. Note that in this case the choice to protect against spillovers affects the equilibrium market structure, in the sense that both the degree of protection from spillovers and the equilibrium market structure are simultaneously determined as a part of equilibrium outcome.

The rest of the paper is organized as follows: in section 2 we present the basic model in which spillovers are assumed exogenous to the firms and provide a parameterized example that illustrates the relationship between the market concentration and market size for different levels of spillovers. In section 3, we allow the firms to eliminate give away spillovers by means of some private protection if they find it optimal and study how this added feature affects the relationship between the market size and concentrations for different levels of initial or ex ante spillovers. Moreover, we also study how the effectiveness of investment in quality improvement and the firm's cost of protection affect firms' decision whether or not to manage spillovers. 
Finally, in section 4 we make some concluding remarks.

\section{The Basic Model}

Much like Sutton (1991) or Sutton, (2007) we also exploit essentially the same threestage game setup in our basic model. In the first stage firms decide whether or not to enter the market and the firms that enter incur sunk entry cost, $F_{0}$. In the second stage the firms choose sunk investment in the quality of the product, which we refer to as R\&D investment. Finally, in the last stage, $N$ firms which entered the market simultaneously choose quantities, $x_{i}$. The total cost of choosing quality level $u_{i}$ for firm $i$ is $F_{i}=F_{0}+u_{i}^{\beta}$, where $u_{i}$ is the quality level of good $i, F_{0}$ is a setup cost, and $\beta>1$ is a model parameter that measures the effectiveness of $\mathrm{R} \& \mathrm{D}$ in raising quality. A lower value of $\beta$ means that a given level of fixed $R \& D$ outlays leads to a greater increase in quality. When $\beta$ tends to infinity, $\mathrm{R} \& \mathrm{D}$ investment becomes more ineffective in enhancing quality. We consider R\&D investment as an instrument to produce product innovations (product quality), which are valued by consumers. Due to spillovers, those innovations can be simultaneously developed by all firms in the market and the examples of such a kind of product innovation could be, for instance, new models or modifications of mobile phones, personal computers, or automobiles.

Consumers, who are (as in Sutton, 1991, and 2007) assumed to be homogenous in valuation of quality, buy a good from firm $i$, based on the observed quality $u_{i}$. A typical consumer's utility function is of the form

$$
U=(u x)^{\delta} z^{1-\delta}
$$

where $z$ is the outside good, and $x$ is the "quality" good, $u$ reflects the perception of good $x^{\prime} s$ quality and is basically of ordinal property.

We start solving the model backward. Each firm offers a single good with quality $u_{i}$ at price $p_{i}$. Now, the consumer after observing prices and qualities of all firms, chooses to buy from the one, which has the highest $u_{i} / p_{i}$ ratio. For firms to have positive sales in equilibrium, we must have that 


$$
u_{i} / p_{i}=u_{j} / p_{j} \text { for any } i \text { and } j .
$$

With the given Cobb-Douglas form of utility function, let $\delta$ be the share of income spent on the "quality" good (for derivations of that see Appendix 5.1). Following the notation of Sutton (2007), we define total spending on "quality good" in the market as $S=\sum_{j=1}^{N}\left(p_{j} x_{j}\right)$. Note that $S$ is the key parameter that serves as the measures of the market size. Also, we define $u_{i} / p_{i}=u_{j} / p_{j}=1 / \lambda$, where $\lambda$ can be interpreted as the price of good $x$ with a unit quality. Now, if the price of a good $x$ with a unit quality is $\lambda$, the price of a good with quality $u_{i}$ is $p_{i}=\lambda u_{i}=S u_{i} / \sum_{j=1}^{N}\left(u_{j} x_{j}\right)^{3}$.

At the last stage of the game, investment in qualities are already sunk, and firms simultaneously choose quantities to be sold to maximize profits. Firm $i$ solves:

$$
\begin{gathered}
\max _{x_{i}} \Pi_{i}=p_{i} x_{i}-c x_{i}=\lambda u_{i} x_{i}-c x_{i} \\
F O C\left(x_{i}\right): \lambda u_{i}+u_{i} x_{i} \frac{d \lambda}{d x_{i}}-c=0 \\
u_{i} x_{i}=\frac{S}{\lambda}-\frac{c S}{\lambda^{2} u_{i}}
\end{gathered}
$$

Summing up for all $j=1, \ldots, N$, we obtain:

\footnotetext{
${ }^{3}$ If we divide $S$ by the total quantity of good $x$ sold (weighed by quality), $\sum_{j=1}^{N}\left(u_{j} x_{j}\right)$, then $S / \sum_{j=1}^{N}\left(u_{j} x_{j}\right)=\lambda$
} 


$$
\begin{aligned}
\sum_{j=1}^{N}\left(u_{j} x_{j}\right) & =\frac{N S}{\lambda}-\frac{c S}{\lambda^{2}} \sum_{j=1}^{N} \frac{1}{u_{j}} \\
\frac{S}{\lambda} & =\frac{N S}{\lambda}-\frac{c S}{\lambda^{2}} \sum_{j=1}^{N} \frac{1}{u_{j}} \\
\lambda & =\frac{c}{N-1} \sum_{j=1}^{N} \frac{1}{u_{j}} \\
x_{i} & =\frac{S(N-1)}{u_{i} c \sum_{j=1}^{N} \frac{1}{u_{j}}}\left[\begin{array}{c}
N-1 \\
u_{i} \sum_{j=1}^{N} \frac{1}{u_{j}}
\end{array}\right] \\
\Pi_{i} & =S\left[1-\frac{(N-1)}{u_{i} \sum_{j=1}^{N} 1 / u_{j}}\right]^{2}
\end{aligned}
$$

Thus, we obtained profit expression for firm $i$, after simultaneous choice of $x_{i}$ by each firm, as a function of quality choice $u_{i}$ :

$$
\Pi_{i}=S\left(1-\frac{N-1}{u_{i} \sum_{j=1}^{N}\left(1 / u_{j}\right)}\right)^{2}=S\left(1-\frac{N-1}{1+u_{i} \sum_{j \neq i}\left(1 / u_{j}\right)}\right)^{2}
$$

In the second stage we, however, introduce the effect of spillovers into product quality. Firms choose the optimal level of investment in quality $u_{i}$, while for consumers firm's $i$ perceived product quality would be effectively $u_{i}^{*} \geq u_{i}$. The reason for that are spillovers from other firms in the industry. Similar to Spence (1984) and Kamien et al. (1992), we define $u_{i}^{*}$ in a linear way as

$$
u_{i}^{*}=u_{i}+\sum_{j \neq i} \theta u_{j}
$$

where $\theta$ is an industry spillover parameter such that $\theta \in[0,1)$. We assume for the sake of simplicity the symmetry between the receiving and give away spillovers for each firm in the industry so that $u_{i r}=u_{i g}=u_{i}$ for each firm (where " $r$ " stands for 
receiving and " $g$ " stands for give away spillovers). Finally, $u_{j}$ is the quality choice by each of the other $N-1$ firms. So firm's $i$ effective quality comprises from the quality choice $u_{i}$ of the given firm $i$, and the fraction $\theta$ of the quality choices of other firms, which enter $u_{i}^{*}$ through spillovers.

In other words, $u_{i}^{*}$ includes both the features and qualities developed by firm $i$, and some portion of features and qualities developed independently by other firms in the market, and, as discussed in the introduction, the channels via which this transfer of knowledge takes place are reverse-engineering, labor force flows among firms, strategic alliances between firms, knowledge dispersion to competitors through "vertical channel" (supplier-client), etc.

With this definition of spillovers, the profit expression to be used in the second stage now becomes:

$$
\Pi_{i}=S\left(1-\frac{N-1}{u_{i}^{*} \sum_{j=1}^{N}\left(1 / u_{j}^{*}\right)}\right)^{2}=S\left(1-\frac{N-1}{1+u_{i}^{*} \sum_{j \neq i}\left(1 / u_{j}^{*}\right)}\right)^{2}
$$

When firm $i$ makes a decision about $u_{i}$, it compares the marginal benefit with the marginal cost of the investment in quality.

The marginal benefit from investing in quality is:

$$
\frac{d \Pi_{i}}{d u_{i}}=\frac{\partial \prod_{i}}{\partial u_{i}^{*}} \frac{d u_{i}^{*}}{d u_{i}}+\sum_{j \neq i} \frac{\partial \Pi_{i}}{\partial u_{j}^{*}} \frac{d u_{j}^{*}}{d u_{i}}
$$

Now, $\frac{d u_{i}^{*}}{d u_{i}}=1$ and $\frac{d u_{j}^{*}}{d u_{i}}=\theta$ from (3). Thus,

$$
\frac{\partial \Pi_{i}}{\partial u_{i}^{*}}=2 S\left(1-\frac{N-1}{1+u_{i}^{*} \sum_{j \neq i}\left(1 / u_{j}^{*}\right)}\right) \frac{N-1}{\left(1+u_{i}^{*} \sum_{j \neq i}\left(1 / u_{j}^{*}\right)\right)^{2}} \sum_{j \neq i}\left(1 / u_{j}^{*}\right)
$$




$$
\frac{\partial \prod_{i}}{\partial u_{j}^{*}}=2 S\left(1-\frac{N-1}{1+u_{i}^{*} \sum_{j \neq i}\left(1 / u_{j}^{*}\right)}\right) \frac{N-1}{\left(1+u_{i}^{*} \sum_{j \neq i}\left(1 / u_{j}^{*}\right)\right)^{2}}\left(-\frac{u_{i}^{*}}{\left(u_{j}^{*}\right)^{2}}\right)
$$

Imposing the symmetry condition, where $u_{i}=u_{j}=u$, from (3) we have:

$$
\begin{aligned}
& u_{i}^{*}=u_{i}+\sum_{j \neq i} \theta u_{j}=u+\theta(N-1) u=u(1+(N-1) \theta) ; \\
& u_{j}^{*}=u_{j}+\theta u_{i}+\sum_{k \neq i, k \neq j} \theta u_{k}=u+\theta u+\theta(N-2) u=u(1+(N-1) \theta) ; \\
& \text { and } u_{i}^{*}=u_{j}^{*}=u^{*}=u(1+(N-1) \theta) .
\end{aligned}
$$

Substituting symmetry conditions into (6) and (7), we obtain expression for $\frac{d \Pi_{i}}{d u_{i}}$ :

$$
\frac{d \Pi_{i}}{d u_{i}}=\frac{2 S(N-1)^{2}(1-\theta)}{N^{3} u(1+(N-1) \theta)}
$$

Also, $\frac{d F_{i}}{d u_{i}}=\beta u^{\beta-1}$. Now, with $\frac{d \Pi_{i}}{d u_{i}}=\frac{d F_{i}}{d u_{i}}$,

$$
\begin{gathered}
\frac{2 S(N-1)^{2}(1-\theta)}{N^{3} u(1+(N-1) \theta)}=\beta u^{\beta-1} \\
u^{\beta}=\frac{2 S(N-1)^{2}(1-\theta)}{N^{3} \beta(1+(N-1) \theta)} \\
F_{i}=\frac{2 S(N-1)^{2}(1-\theta)}{N^{3} \beta(1+(N-1) \theta)}+F_{0},
\end{gathered}
$$

which gives us optimal investment into quality for each firm in symmetric equilibrium, given $N$ firms entered ${ }^{4,5}$.

\footnotetext{
${ }^{4}$ For a more general case of endogenous sunk cost model (Sutton 1991, 53-54), the condition $\frac{d \Pi_{i}}{d u_{i}}=\frac{d F_{i}}{d u_{i}}$ does not always determine the number of firms entering the market. For a too small market size, the condition $\left.\frac{d \Pi_{i}}{d u_{i}}\right|_{u=0} \leq\left.\frac{d F_{i}}{d u_{i}}\right|_{u=0}$ holds. For such cases, the marginal cost of investment into quality exceeds the marginal profit, and firms do not invest into endogenous sunk costs. As a result, the number of firms is determined by fixed entry outlays $F_{0}$. With no endogenous sunk cost, as market size increases, there are more firms in the market. However, at some value of $S$ firms start to invest into endogenous sunk cost, and there appears the limit to number of firms entering the market, in other words, the lower bound on market concentration.

In our case, however, $\left.\frac{d \Pi_{i}}{d u_{i}}\right|_{u=0} \leq\left.\frac{d F_{i}}{d u_{i}}\right|_{u=0}$ is never the case, thus, even for small market size we impose condition $\frac{d \Pi_{i}}{d u_{i}}=\frac{d F_{i}}{d u_{i}}$ to determine for optimum value of sunk cost investment into $u$.

${ }^{5}$ Appendix 5.4 also demonstrates that $d\left(\frac{d \Pi_{i}}{d u_{i}}-\frac{d F_{i}}{d u_{i}}\right) / d u_{i}<0$ at $u_{i}={\frac{2 S\left(N^{*}-1\right)^{2}(1-\theta)}{N^{* 3} \beta\left(1+\left(N^{*}-1\right) \theta\right)}}^{1 / \beta}$. Therefore, the second order condition is satisfied.
} 
Finally, to compute the number of firms entering in the first stage, we impose zero profit condition (free entry): $F_{i}=\Pi_{i}$. Expression for $\Pi_{i}$ in symmetric equilibrium becomes $\Pi_{i}=S\left(\frac{1}{N}\right)^{2}$, with (9) we obtain:

$$
\begin{aligned}
\frac{2 S(N-1)^{2}(1-\theta)}{N^{3} \beta(1+(N-1) \theta)}+F_{0} & =S\left(\frac{1}{N}\right)^{2} \\
\left(S-F_{0} N^{2}\right) \beta(1+\theta(N-1)) N & =2 S(N-1)^{2}(1-\theta)
\end{aligned}
$$

The relation (10) above is an implicit equation for the optimal number of firms, $N^{*}$, from which we can express $N^{*}$ as a function of market size $S$ and parameters $\left(F_{0}, \theta, \beta\right)$.

\subsection{Spillovers and the lower bound of concentration: para- meterized example}

Before presenting the parameterized example, we show formally how the equilibrium number of firms is determined if $S$ approaches infinity. Also we use the Herfindahl index, $H$, as the standard measure of market concentration that in the symmetric equilibrium assumes the value $H=1 / N^{*}$. We rewrite (10) as:

$$
\begin{aligned}
\frac{F_{0}}{S} & =\left(\frac{1}{N}\right)^{2}-\frac{2(N-1)^{2}(1-\theta)}{N^{3} \beta(1+(N-1) \theta)} \\
\frac{F_{0}}{S} & =\frac{N \beta(1+(N-1) \theta)-2(N-1)^{2}(1-\theta)}{N^{3} \beta(1+(N-1) \theta)}
\end{aligned}
$$

For $\theta<\frac{2}{2+\beta}$ there is a finite value of $N^{*}$, which satisfies the condition (11) as $S \rightarrow \infty$ (see Appendix 5.3 for the formal proof of this result). On the other hand, for $\theta>\bar{\theta}=\frac{2}{2+\beta}$, as $S$ tends to infinity, it has to be that $N^{*}$ also tends to infinity, in order for (11) to be satisfied. Moreover, $N^{*}$ approaches infinity at a different rate, depending on the value of the spillover parameter, with higher spillovers leading to a higher speed at which $N^{*}$ increases. 
Note that the point at which the equilibrium number of firms $N^{*}$ starts to rise beyond a finite limit (as a result of $S$ tend to infinity) depends on $\beta$; if $\beta$ is high, the concentration bound disappears for much lower spillover values. As expected, if R\&D investment is not very effective in raising quality ( $\beta$ is high), firms do not invest much in the $\mathrm{R} \& \mathrm{D}$, and so barriers to entry are lower. In such circumstances a lower level of spillovers is needed for the number of entrants to grow without limit as market size increases leading the lower bound of concentration to collapse to zero.

In the example below, we set parameter values $\beta=2, F_{0}=0.5$, and solve for the equilibrium $N^{*}$ for different values of $\theta$. The graph below demonstrates how the equilibrium concentration $\left(1 / N^{*}\right)$ is changing relative to market size $S$, for different values of $\theta$. For example, the lowest full line represents the limiting case where $\theta=1$ - concentration approaches zero, and equilibrium number of firms approaches infinity. The upper dotted line represents the case $\theta=0.001$ (spillover effect close to zero ${ }^{6}$ ) concentration approaches approximately 0.4 , and the equilibrium number of firms is finite.

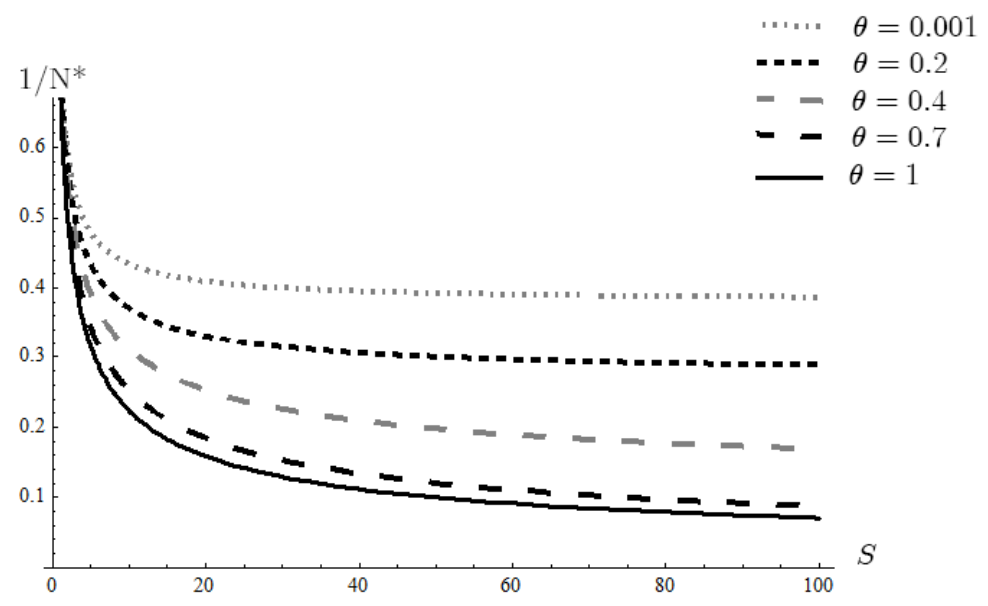

Figure 1. Concentration and market size, for different values of $\theta$

As we can see from the parameterized example, the lower bound on equilibrium

\footnotetext{
${ }^{6}$ For the parametric estimates we take $\theta=0.001$ as an approximation of $\theta=0$, because taking the value $\theta=0$ does not allow us to calculate equilibrium number of firms $N^{*}$ due to the "division by zero" problem.
} 
concentration level $\left(1 / N^{*}\right)$ decreases with spillovers, and for the values of spillover parameter $\theta>\bar{\theta}=1 / 2$, it becomes equal to zero.

Thus our analysis suggests a testable hypothesis that industries with low spillovers (for which endogenous sunk costs matter) will remain highly concentrated, and industries with high spillovers will become fragmented, as size of the market increases.

Further we demonstrate how the effect of spillovers will decrease the incentives to invest into endogenous sunk costs. We will express equilibrium expenditures on quality (for different $\theta$ ) by individual firm and by the whole industry, as a function of $S$. To do that, we use the solution for $N$ from (10) and plug it into the expression for endogenous sunk costs of individual firm, (9). The corresponding graph is below.

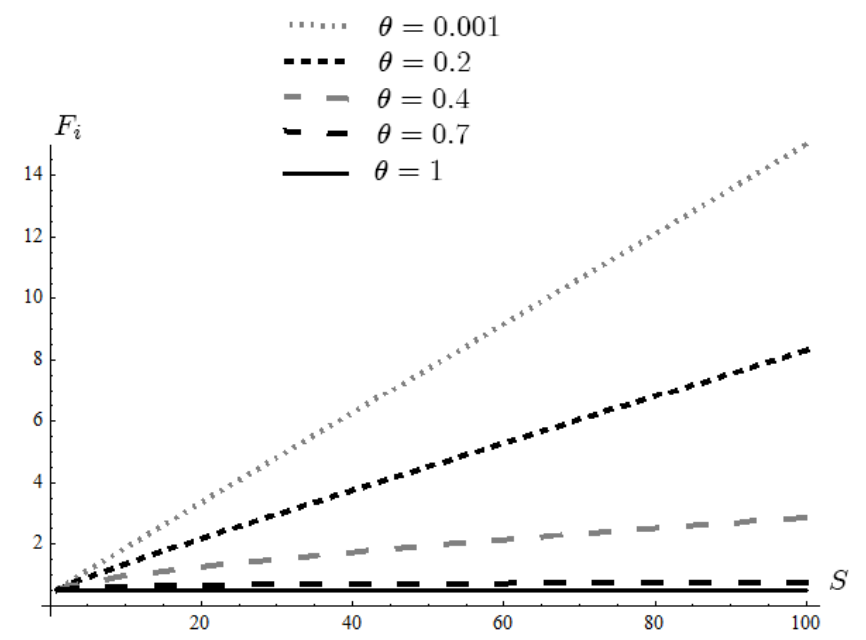

Figure 2. Firm's expenditures on quality and market size, for different values of $\theta$

The higher $\theta$ is, the lower is individual spending on quality. Investment in the case of almost no spillovers $(\theta=0.001)$, is much higher compared with higher $\theta$ values, and for $\theta=1$ there is no endogenous sunk costs investment. For low spillovers, the effect of market size $S$ on R\&D investment is very significant as individual firm investment into quality $F_{i}$ increases significantly as market size $S$ grows. However, as spillovers increase, R\&D investment remains at the negligible level, and $S$ has almost no effect on R\&D.

The same result holds for the total industry investment in quality improvement. 
Although an increase in spillovers induces entry of new firms, the disincentive effect of increased $\theta$ more than offsets it so the total industry R\&D investment falls as well. Thus, we would obtain an analogous graph for the industry total R\&D expenditure as that for the firm's individual R\&D investment (Appendix 5.6). Therefore, our next testable hypothesis is that the higher knowledge spillovers are, the lower R\&D expenditures are by both individual firm and an industry as a whole, other things being equal. In other words, increasing the size of the market leads to an increase in $R \& D$ expenditure, but in the industries with high spillovers this increase in $R \& D$ is happening at a much lower rate than in the industries with low spillovers.

The intuition for the above results, summarized in Figures 1 and 2, goes roughly as follows: the impact of giving away spillovers becomes stronger than its receiving counterpart as the industry spillover parameter rises. Each firm realizes that all other firms will free-ride on its investment, and also it would be optimal to freeride on others' investment. Thus the consequence of rising spillovers are decreasing endogenous sunk costs (see Fig. 2), larger entry in the industry and, other things being equal, lower market concentration (see Fig. 1). Once spillovers surpass the threshold of $\bar{\theta}=\frac{2}{2+\beta}$, the disincentives to invest become so strong that the lower bound of concentrations disappears, that is, $N^{*}$ tends to infinity as market sizes increases.

To see more deeply the forces at work, it would be instructive to decompose the change of endogenous sunk costs due to an increase in market size $\left(d F_{i} / d S\right)$ in its entry and escalation effects. That is, $d F_{i} / d S=\left(\partial F_{i} / \partial N\right) \times(d N / d S)+\partial F_{i} / \partial S$ where the first part $\left(\partial F_{i} / \partial N\right) \times(d N / d S)$ stands for "entry effect" while the second part $\left(\partial F_{i} / \partial S\right)$, describes "the escalation effect". Recall that the escalation effect is at the heart of the non-fragmented market structure and, consequently, a strictly positive lower bound of concentration. That is, an increase in the market size is accompanied by an escalation of endogenous sunk costs that keeps at bay the entry of new firms and makes market concentration finite even if the market size approaches to infinity. The second entry effect is typically negative ${ }^{7}$ in the presence of spillovers. This

\footnotetext{
${ }^{7}$ It turns out that for very small or zero spillovers this derivative can be positive. As Vives, (2008) showed, the entry of new firms has two opposing effects on the R\&D investment: the direct demand
} 
implies that the increased size of the market would result in some entry that would in turn negatively affect the investment in $R \& D$ or endogenous sunk costs due to the fact that the incentives to invest decrease with more firms in the market (that is, $\left.\left(\partial F_{i} / \partial N\right) \times(d N / d S)<0\right)$. This entry effect, however, is of rather limited power compared to the escalation effect when spillovers are small (that is, for $\theta<\bar{\theta}=\frac{2}{2+\beta}$ ) implying that $d F_{i} / d S>0$. In other words, the entry effect becomes stronger (in absolute value) relative to the "escalation effect" as spillover parameter increases (that is, $\left.d^{2} F_{i} / d S d \theta<0\right)$. When spillovers reach and exceed $\bar{\theta}$ the entry effect completely offsets the escalation effect in the limit resulting in a non-fragmented market structure with zero lower bound of concentrations (technically, it implies that $\lim _{S \rightarrow \infty}\left(1 / N^{*}\right)=0$ and $\lim _{S \rightarrow \infty}\left(d F_{i} / d S\right)=0$ when $\left.\theta \geq \frac{2}{2+\beta}\right)^{8}$.

Note also the disincentive effect that spillovers exhibit on a firm's profit: as spillover parameter increases, a firm profits decline, that is, $\frac{d \Pi_{i}}{d \theta}=\frac{\partial \Pi_{i}}{\partial N^{*}} \frac{d N^{*}}{d \theta}+\frac{\partial \Pi_{i}}{\partial \theta}<$ 0 . Interestingly enough, the negative sign does not come from the direct effect of spillovers since it vanishes (that is, $\frac{\partial \Pi_{i}}{\partial \theta}=0$ ) due to the symmetry in receiving and give away spillovers. Apparently, the key is in the indirect effect that turns out to be negative. That is, the equilibrium profit declines in the number of firms while the equilibrium number of firms increases with spillovers due to the mechanism described above (that is, $\frac{\partial \Pi_{i}}{\partial N^{*}}<0$, and $\frac{d N^{*}}{d \theta}>0$; see Appendix 5.2 for the complete proof).

\section{$3 \quad$ Managing Spillovers}

Following Schumpeter's argumentation, firms need to expect future profits (rents), in order to have incentives to invest in $\mathrm{R} \& \mathrm{D}$ innovations. As we just saw above, however, increased spillovers have a negative impact on a firm's profit so a firm may consider the prevailing giving away spillovers to be excessive and may try to curb

and the indirect price pressure effects that work in opposite directions. The direct demand effect typically dominates the price pressure effect, and $R \& D$ decreases with the number of firms. It is possible, however, that price pressure effect dominates the demand effect so that an increase in the number of firms causes an increase in R\&D expenditures (see the Appendix 5.5 for more detailed discussion on this points).

${ }^{8}$ Formally, "escalation effect" and "entry effect" are derived in the Appendix 5.5, where we also present how the two effects change as market size $S$ approaches infinity. 
them. In this light, one typically thinks of patents and copyrights as the means to prevent spillovers and restore the incentives for innovation. Cohen and Levin (1989), however, provide an extensive review of literature on effectiveness of patenting in different industries and come to the conclusion that in many industries (machinery, electronics, food processing, etc.) only a negligible share of firms use patents. Instead, firms use other measures to protect R\&D investment from spillovers like: secrecy, product complexity, ability to learn quickly. As Shenkar, 2010 noted "...[L]egal protections have weakened at the same time that codification, standardization, new manufacturing techniques, and growing employee mobility making copying easier". Along the same line, Scotchmer (2004) defines so called private or technical IPR protection as an alternative to legal patents.

So we now allow firms to use costly measures to privately protect their R\&D investment from spillovers. As we argued in the introduction, one situation when private protection against spillovers may emerge is the case when adopting quality improvements of other firms by firm i represents IPR violation and this would be especially the case if the public IPR protection is not possible or, more likely, if it is not effective (say, due to enforceability problems, high litigation costs, etc.). For instance, in the case when spillovers are realized through reverse-engineering, such a costly private protection measure would be making the product more complicated to disassemble and copy. If spillovers are realized through the labor force flows between firms, costly private protection measures may mean that companies pay key employees more to prevent them from leaving as, for instance, in Zabojnik (2002), Gersbach and Schmutzler (2003). They interpret the costly prevention of spillovers as extra wages the workers are paid so that they do not leave the firm and do not transfer important information to competitors; and in the case of receiving spillovers - this is the extra wage the firm has to pay to the competitor's workers to be able to hire them. Atallah (2004) interprets this prevention of spillovers as any costly activity which is enhancing secrecy, and obtains a result similar to ours: higher ex ante spillovers and lower costs of secrecy implementation would result in higher secrecy adoption.

A somewhat different notion of endogenous spillovers than the one we use here 
was adopted in the early literature on spillovers where endogenous spillovers typically mean that firms deliberately fully or partially share their research output with each other. So firms cooperate in R\&D by setting research joint ventures or research consortia in which they endogenously and cooperatively set both giving and receiving spillovers $^{9}$.

Finally, note that unlike in the above literature on cooperation in $R \& D$, the notion of endogenous knowledge spillovers in our context has the meaning of unilaterally (non-cooperativley) curbing the give-away spillovers.

By decreasing the spillover $\theta$, firm $i$ will also decrease the effective qualities of all other firms, which will in turn have a positive effect on its profits. (From (7), we can see that $\frac{\partial \Pi_{i}}{\partial u_{j}^{*}}<0$, for all $j \neq i$ ).

In this section we assume that firms have an option to adopt costly protection against spillovers. Thus, firms are able to restrain the size of spillovers if they find them too large and if this is not too costly to do. For simplicity, we assume that firm $i$ has a choice to decrease spillovers from $\theta$ to 0 . In this case, the costs would be $F_{i}=F_{0}+\alpha u_{i}^{\beta}$, with $\alpha>1$, where $\alpha$ is a cost shifter that reflects the fact that private protection of quality is costly as compared to costs $F_{i}=F_{0}+u_{i}^{\beta}$, when firm $i$ does not prevent spillovers. On the benefit side, if firm $i$ protects its investment from spillovers, its effective quality remains the same (given that no other firm chooses to protect its investment): $u_{i}^{*}=u_{i}+\sum_{j \neq i} \theta u_{j}$, but the effective quality of all other firms decreases: $u_{j}^{*}=u_{j}+\sum_{k \neq j, k \neq i} \theta u_{k}$, as compared to $u_{j}^{*}=u_{j}+\theta u_{i}+\sum_{k \neq j, k \neq i} \theta u_{k}$.

We look for the set of parameters which satisfy the conditions for symmetric Nash equilibria, where all firms either simultaneously choose to protect their investment from spillovers, or they do not protect.

The timing of the model is much like in the previous section, with one more step introduced. In the first stage firms decide whether or not to enter the market, in the second stage, the firms that entered choose sunk entry cost, $F_{0}$ and also sunk

\footnotetext{
${ }^{9}$ The pioneering article in this sense was the Kamian et al. 1992, followed by Poyago-Theotoky (1999), Amir et al. (2003), and Tesoriere (2008). See also DeBondt (1996) for an early survey about the role of spillovers in R\&D incentives who, among other things, noted that in reality spillovers are endogenous to a large extent, and possibly interacting with exogenous information leakages.
} 
investment in quality of the product. In the third stage firms decide simultaneously whether to protect their investment from spillovers or not. Finally, in the last stage, $N$ firms which entered the market simultaneously choose quantities, $x_{i}$.

First, consider the equilibria where none of the firms use protection against spillovers. As in the previous section, (9) defines costs of investment for firm $i$, and profit is $S\left(\frac{1}{N}\right)^{2}$. Now, assume that a firm $i$ decides to deviate and starts protecting from spillovers at stage 3. Profit expression for firm $i$ becomes:

$$
\Pi_{i}^{D}=S\left(1-\frac{(N-1)}{1+u_{i}^{*} \sum_{j \neq i}\left(1 / u_{j}^{*}\right)}\right)^{2}
$$

where $u_{i}^{*}=u_{i}+\sum_{j \neq i} \theta u_{j}$, and $u_{j}^{*}=u_{j}+\sum_{k \neq j, k \neq i} \theta u_{k}$. Now, in symmetric case, $u_{i}^{*}=$ $u+\theta(N-1) u$, and $u_{j}^{*}=u+(N-2) \theta u$. Profit expression becomes:

$$
\begin{aligned}
\Pi_{i}^{D} & =S\left(1-\frac{(N-1)}{1+u_{i}^{*} \sum_{j \neq i}\left(1 / u_{j}^{*}\right)}\right)^{2}=S\left(1-\frac{(N-1)}{1+\frac{u(1+\theta(N-1))(N-1)}{u(1+\theta(N-2))}}\right)^{2}= \\
& =S\left(\frac{(2 N-3) \theta+1}{N(\theta(N-1)+1)-\theta}\right)^{2}>S\left(\frac{1}{N}\right)^{2}
\end{aligned}
$$

Cost expression for firm $i$ becomes now $F_{i}^{D}=F_{0}+\alpha u^{\beta}=F_{0}+\alpha \frac{2 S(N-1)^{2}(1-\theta)}{N^{3} \beta(1+(N-1) \theta)}$. Now, if

$$
\Pi_{i}^{D}-F_{i}^{D}=S\left(\frac{(2 N-3) \theta+1}{N(\theta(N-1)+1)-\theta}\right)^{2}-F_{0}-\alpha \frac{2 S(N-1)^{2}(1-\theta)}{N^{3} \beta(1+(N-1) \theta)} \leq 0
$$

where $N$ is such that: $\frac{2 S(N-1)^{2}(1-\theta)}{N^{3} \beta(1+(N-1) \theta)}+F_{0}=S\left(\frac{1}{N}\right)^{2} \quad$ (zero profit condition)

firm $i$ does not have incentives to deviate from symmetric equilibria, in which none of the firms protects from spillovers.

For the set of parameter values $S=100, \alpha=\{1,5 ; 2\}, F_{0}=0.5$, we define such a 
combination of values of spillover size $\theta$ and investment cost parameter $\beta$, that (12) holds.

In the Figure 3 below the blue area defines the set of parameters $\beta$ and $\theta$, for which "no protection" equilibrium exist. We can see that for low enough spillovers, firms will not undertake costly protection measures. However, for high enough values of $\beta$, firms will not tolerate even small spillovers. For low effectiveness of $R \& D$ in raising quality (high $\beta$ ), the endogenous sunk cost ( $\mathrm{R} \& \mathrm{D}$ investment level) $u^{\beta}$ becomes smaller (see the expression 9) and more firms enter the market. With more firms in the market, the benefit from protection is higher, and the firm is willing to undertake it even for small spillovers.
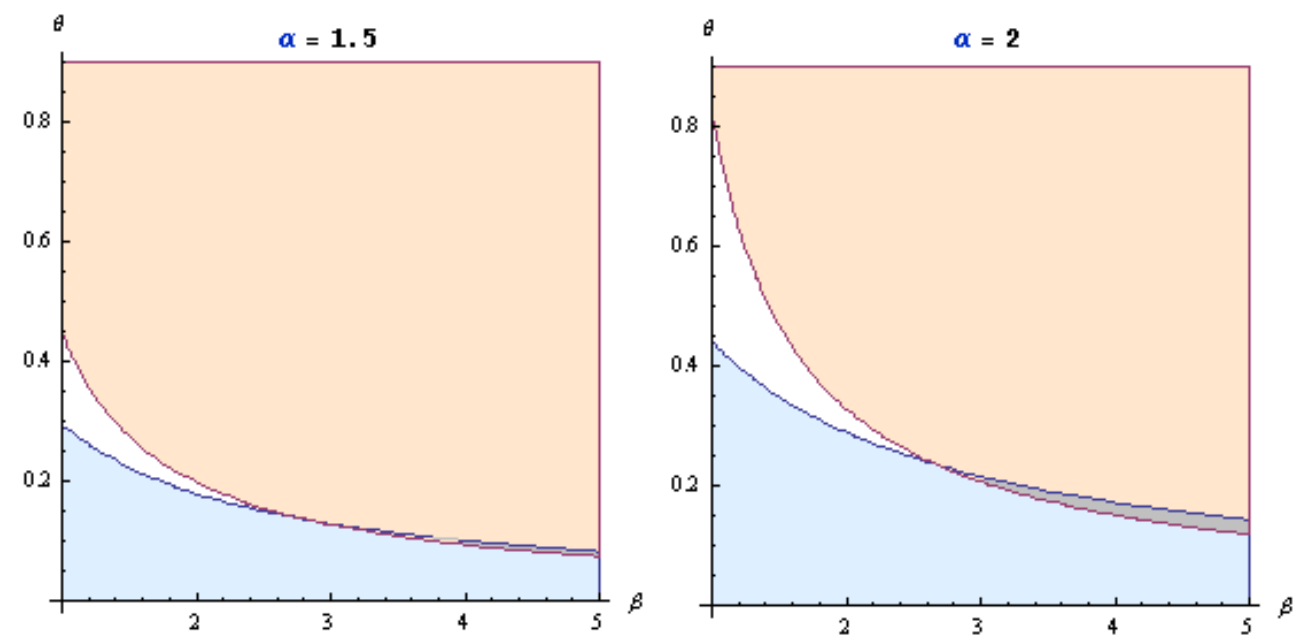

Figure 3. "No protection" (blue, below) and "Protection" (orange, above) symmetric pure strategy Nash equilibria

Now, consider the equilibria where all firms choose to manage spillovers. Given that all firms have chosen protection (implying that $\theta=0$ ), the firms choose optimally investment level into quality. From (8), we obtain that $\frac{d \Pi_{i}}{d u_{i}}=\frac{2 S(N-1)^{2}}{N^{3} u}$, and $\frac{d F_{i}}{d u_{i}}=$ $\beta \alpha u^{\beta-1}$. Profit maximization requires that $\frac{d \Pi_{i}}{d u_{i}}=\frac{d F_{i}}{d u_{i}}$, and by symmetry assumption, $u^{\beta}=\frac{2 S(N-1)^{2}}{N^{3} \beta \alpha}$.

Much as in the previous section, we have the zero-profit condition, 


$$
\alpha \frac{2 S(N-1)^{2}}{N^{3} \beta \alpha}+F_{0}=S\left(\frac{1}{N}\right)^{2}
$$

that determines the number of firms which enter the market.

Now, assume that a firm $i$ decides to deviate and stops protecting from spillovers at stage 3. Profit expression for firm $i$ is then:

$$
\Pi_{i}^{D}=S\left(1-\frac{(N-1)}{1+u_{i}^{*} \sum_{j \neq i}\left(1 / u_{j}^{*}\right)}\right)^{2}
$$

where $u_{i}^{*}=u_{i}$, and for all other firms $u_{j}^{*}=u_{j}+\theta u_{i}$. Now, in the symmetric case, $u_{i}^{*}=u$, and $u_{j}^{*}=u(\theta+1)$, and profit expression becomes:

$$
\begin{aligned}
\Pi_{i}^{D} & =S\left(1-\frac{(N-1)}{1+u_{i}^{*} \sum_{j \neq i}\left(1 / u_{j}^{*}\right)}\right)^{2}=S\left(1-\frac{(N-1)}{1+\frac{u(N-1)}{u(\theta+1))}}\right)^{2}= \\
& =S\left(\frac{(2-N) \theta+1}{N+\theta}\right)^{2}<S\left(\frac{1}{N}\right)^{2}
\end{aligned}
$$

The cost expression for a deviant firm $i$ becomes $F_{i}^{D}=F_{0}+u^{\beta}=F_{0}+\frac{2 S(N-1)^{2}}{N^{3} \beta \alpha}$.Now, if

$$
\Pi_{i}^{D}-F_{i}^{D}=S\left(\frac{(2-N) \theta+1}{N+\theta}\right)^{2}-F_{0}-\frac{2 S(N-1)^{2}}{N^{3} \beta \alpha} \leq 0
$$

where $N$ is such that: $\alpha \frac{2 S(N-1)^{2}}{N^{3} \beta \alpha}+F_{0}=S\left(\frac{1}{N}\right)^{2}$ (zero profit condition)

firm $i$ does not have incentives to deviate from symmetric equilibria, where all firms protect against spillovers.

For the same set of parameter values, we define such a combination of values of spillover size $\theta$ and investment cost parameter $\beta$, that (13) holds.

In the figure above, the orange area defines the set of parameters $\beta$ and $\theta$, for 
which "protection" equilibrium will exist. We can see that for high enough spillovers firms will not deviate from protection.

For the values of parameters that are not in the shaded areas there is no symmetric equilibria in pure strategies. For such values of parameters outside the orange area, if all firms protect, there are always incentives for one firm to deviate to "no protection". On the other hand, if parameter values are outside the blue area, the firm always has incentives to deviate from "no protection" behavior and starts protecting its quality features. Also, there is an area (gray) on the figure above where both "protection" and "non protection" equilibria exist. That is, if all firms choose to protect their investment from spillovers, each single firm would not prefer to deviate to not protecting; on the other hand, if all firms choose not to protect, each single firm would not prefer to deviate and start protecting.

Also, as $\alpha$ increases from 1.5 to 2, "no protection" (blue) area become larger - it is now more costly to protect against spillovers, and "no protection" equilibrium is more likely other things being equal. On the contrary, the "protection" (orange) area shrinks as it becomes more costly to protect.

\subsection{The lower bound of concentration when spillovers are managed}

As Figure 3 demonstrates, for different values of $\theta$ different equilibria will emerge. In the following analysis we fix cost parameters $\beta=2, \alpha=2$, and draw the concentration schedule as a function of market size for different $\theta$ (Figure 4). 


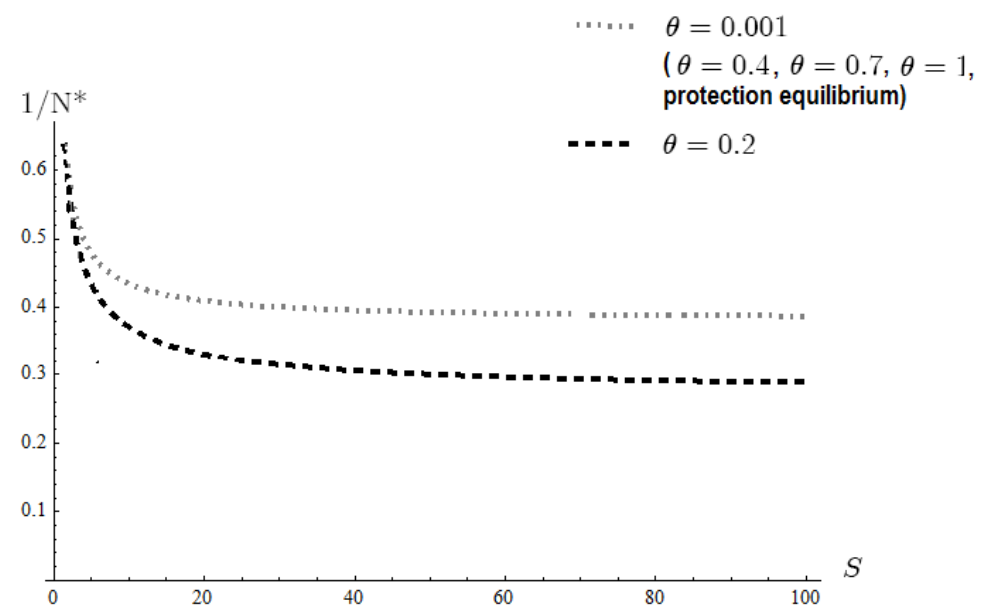

Figure 4. Concentration and market size, for different values of $\theta$

For $\theta=0.001$ and $\theta=0.2$, we have "no protection" equilibria, and the concentration versus market size schedule is the same as in Figure 1. However, for higher values of $\theta$ "protection" equilibria will emerge, meaning that firms will choose to manage spillovers and decrease them to zero. For these cases concentration versus market size schedule again coincides with the upper curve in Figure 1. As a result, we can see that for high values of spillover parameter $\theta$ concentration remains high and does not decrease to zero if we allow firms to protect from spillovers.

In the environment where protection against spillovers is allowed, what matters for the choice of endogenous sunk costs is not the level of ex ante spillovers but the level of ex post spillovers, that under our assumption, completely vanish if firms find it optimal to undertake protective measures. High ex ante spillovers provide incentives for firms to use costly protection against knowledge diffusion and so industries with high exogenous spillovers will not become fragmented if the size of the market increases. This leads us to another testable hypothesis, that industries which are characterized by high ex ante spillovers would not become fragmented as the size of the market increases, provided that firms use protection measures against knowledge diffusion. So the positive lower bound of concentration is preserved in this case. 


\subsection{The lower bound of concentration and effectiveness of sunk costs in raising quality}

An important insight of the endogenous market structure literature is that a "higher" effectiveness of $R \& D$ in raising quality, captured by lower $\beta$ in our setup, implies more concentrated market structure. This happens because when $\beta$ is low, firms find it more attractive to deviate upwards in their $\mathrm{R} \& \mathrm{D}$ spending and so the equilibrium level of $R \& D$ is higher and the number of active firms is lower. However, introducing endogenous protection from spillovers makes this negative relation between $\beta$ and $F_{i}$ not monotonic.

In Figure 5 below we demonstrate how equilibrium firm's R\&D spending $F_{i}$ changes as $\beta$ increases in the setting with endogenous protection against spillovers. As $\beta$ increases, investment into quality is less attractive, and equilibrium sunk costs $F_{i}$ decrease. However, at some level of $\beta$, firms will start to protect against spillovers, which will make R\&D investment into quality again more attractive, irrespectively of the high value of $\beta$. The reason for this is, as indicated above, that decline in cost effectiveness results in the lower equilibrium sunk costs that in turn invites entry of new firms and makes protection more attractive. As a result, equilibrium R\&D spending $F_{i}$ "jumps up", producing the discontinuity in $\beta$ and $R \& D$ relationship.

In this setting with protection against spillovers, $R \& D$ investment does not necessarily decrease in $\beta$. For instance, $\mathrm{R} \& \mathrm{D}$ investment $F_{i}$ for $\theta=0.4$ (right) is not lower than for $\theta=0.2$ (left) for $\beta \geq 1.75$ (see Figure 5) as would be the case with exogenous spillovers ${ }^{10}$.

\footnotetext{
${ }^{10}$ In the setting with exogenous spillovers (Figure 2), we showed that the higher is spillover, the lower is R\&D investment.
} 

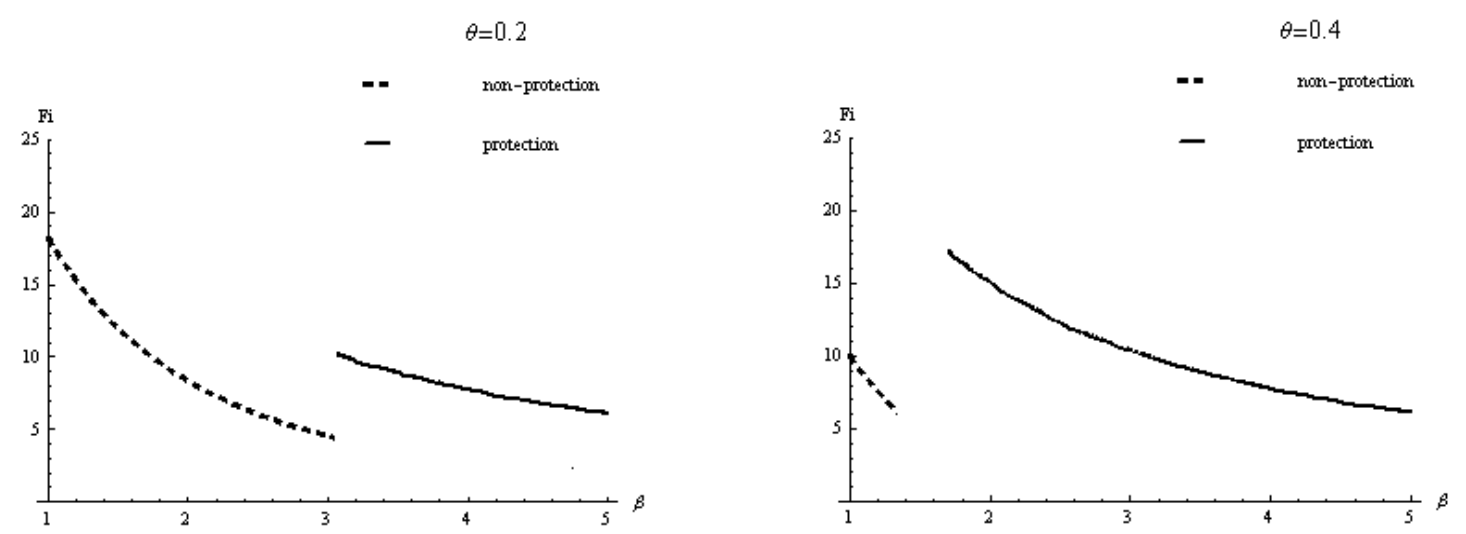

Figure 5. Individual firm's sunk costs $F_{i}$ (R\&D investment) as a function of $\beta$ for $\theta=0.2$ (left) and for $\theta=0.4$ (right)

From the figures above we also conclude, that the value of $\beta$ at which firms start to manage spillovers decreases as spillovers $\theta$ become higher. For example, for $\theta=0.2$, firms will use protection against spillovers in equilibrium for $\beta \geq 3$, while for $\theta=0.4$ firms use protection already for $\beta \geq 1.75$.

We showed how the equilibrium $\mathrm{R} \& \mathrm{D}$ investment changes with $\beta$ in the setting with firms' protection against spillovers. The relationship between $\beta$ and equilibrium number of firms (concentration) is also non-continuous and is driven by similar logic. For instance, for $\theta=0.2$ (as well as for $\theta=0.4$ ), as $\beta$ increases, and R\&D spending $F_{i}$ decreases (see Figure 5). It is now possible for more firms to enter the market of fixed size, and the equilibrium number of firms increases. As a result, the market becomes less concentrated. However, for sufficiently high $\beta$, firms are better off from managing spillovers, which effectively decreases spillovers $\theta$ to zero. This makes investment into quality again more attractive, irrespective of high $\beta$. As a result of higher spending on quality, there are fewer active firms on the market. Thus, there is discontinuity in the $\beta$ and $N^{*}$ relationship, and a drop in the equilibrium number of active firms, as well as a raise in concentration. Detailed description of the relationship between equilibrium number of active firms $N^{*}$ and the cost parameter $\beta$ is provided in the Appendix 5.7, as well as corresponding graphs. 
Therefore, our last testable hypothesis relates $\mathrm{R} \& \mathrm{D}$ expenditures (and market concentration) to the effectiveness of those expenditures, in the sense that lower effectiveness of $\mathrm{R} \& \mathrm{D}$ expenditures (higher $\beta$ ) would not lead to lower endogenous sunk costs if the firm starts to use costly protection against spillovers for higher values of $\beta$. Moreover, if ex ante spillovers are high, firms are more likely to use protection against spillovers even for effective $\mathrm{R} \& \mathrm{D}$ expenditures (low $\beta$ ). This would lead to even higher $R \& D$ expenditures (because of curbed spillovers and low $\beta$ ), and an even more concentrated market structure.

\section{Concluding Remarks}

We used a simple Sutton (2007) model that illustrates the working of endogenous sunk costs and extended it by allowing for spillovers stemming from firms' investment in product quality. In the first part of our paper, we assume that spillovers are exogenous to the firms. The testable hypothesis, given exogenous spillovers (and a large enough market size), is that market concentration and its lower bound will be lower when spillovers are higher and the effectiveness of the endogenous sunk cost in raising quality is lower. In the case when spillover parameter reaches and exceeds the value of $\bar{\theta}=\frac{2}{2+\beta}$, the lower bound on concentration disappears and concentration approaches zero as market size approaches infinity.

In the second part we allow firms to protect their investment against spillovers, if it would be optimal for them. We focus on symmetric pure strategy Nash equilibria, where all firms either protect their investment or not. As a result, for different values of parameters different equilibria may arise. For low values of $\theta$ "no protection" equilibrium exists while for high enough values of $\theta$ and $\beta$ "protection" equilibrium occurs. Contrary to the case of exogenous spillovers, we show that ex ante spillovers may lead to a more concentrated market structure due to the possibility of firms' private protection from spillovers, and this represents another testable hypothesis. It also suggests the related testable hypothesis that lower effectiveness of raising quality (higher $\beta$ ) does not lead to lower endogenous sunk costs, and, consequently, to lower 
market concentration if it triggers firms to use costly protection against spillovers.

Finally, it is worth stressing that our paper is related to three separate topics in industrial organization literature: i) innovation and $R \& D$ incentives, ii) market structure and iii) knowledge spillovers. While the related literature usually studies all three notions separately, commonly assuming market structure and R\&D spillovers as exogenous parameters, we put forward a theoretical model that simultaneously and endogenously determines the equilibrium values of all three features under considerations. 


\section{$5 \quad$ Appendix}

\subsection{Derivation of demand for quality good}

Consumers' maximization problem is:

$$
\begin{aligned}
& \max _{x, z}(u x)^{\delta} z^{1-\delta} \\
& \text { s.t. } p x+p_{0} z \leq I
\end{aligned}
$$

With budget constraint satisfied with equality, $x=\frac{I-p_{0} z}{p}$ and utility function becomes $(u x)^{\delta} z^{1-\delta}=\left(u\left(\frac{I-p_{0} z}{p}\right)\right)^{\delta} z^{1-\delta}$. FOC with respect to $z$ are:

$$
\begin{aligned}
F O C(z) & : \delta\left[u\left(\frac{I-p_{0} z}{p}\right)\right]^{\delta-1} z^{1-\delta} \frac{p_{0} u}{p}=\left[u\left(\frac{I-p_{0} z}{p}\right)\right]^{\delta}(1-\delta) z^{-\delta} \\
p_{0} z & =(1-\delta) I \\
p x & =\delta I
\end{aligned}
$$

\subsection{Derivation of $\frac{d \Pi_{i}}{d \theta}$}

Direct effect of $\theta$ on $\Pi_{i}: \frac{\partial \Pi_{i}}{\partial \theta}$.

Taking the expression for profit (4), it can be seen that $\theta$ enters $\Pi_{i}$ directly only in the expressions for $u_{i}^{*}$ and $u_{j}^{*}$. Therefore,

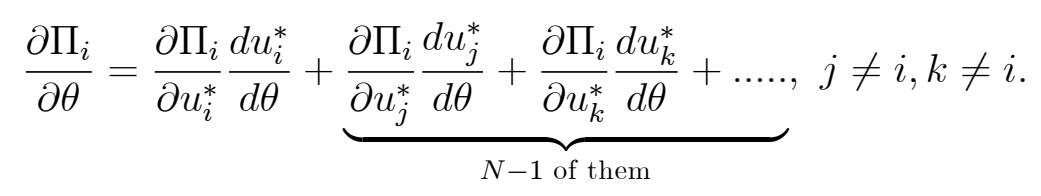

(6) and (7) provide expressions for $\frac{\partial \Pi_{i}}{\partial u_{i}^{*}}$ and $\frac{\partial \Pi_{i}}{\partial u_{j}^{*}} \cdot \frac{d u_{i}^{*}}{d \theta}=\sum_{j \neq i} u_{j}$ and $\frac{d u_{j}^{*}}{d \theta}=u_{i}+\sum_{k \neq i, k \neq j} u_{k}$. With symmetry assumption, $\frac{\partial \Pi_{i}}{\partial \theta}=2 S\left(\frac{1}{N}\right)\left(\frac{N-1}{N^{2}}\right) \frac{N-1}{u} \times(N-1) u-2 S\left(\frac{1}{N}\right)\left(\frac{N-1}{N^{2}}\right) \frac{1}{u} \times$ $(N-1) u \times(N-1)=0$ 
Indirect effect of $\theta$ on $\Pi_{i}: \frac{\partial \Pi_{i}}{\partial N^{*}} \frac{d N^{*}}{d \theta}$.

$\frac{\partial \Pi_{i}}{\partial N^{*}}<0$ from (4). The Figure below shows that the equilibrium number of firms $N^{*}$ is indeed the increasing function of spillover parameter $\theta: \frac{d N^{*}}{d \theta}>0$. Also, for each value of spillover parameter $\theta$ there exists single value of $N^{*}$ (higher than one and finite) which solves zero profit condition (10). Therefore, $\frac{\partial \Pi_{i}}{\partial N^{*}} \frac{d N^{*}}{d \theta}<0$

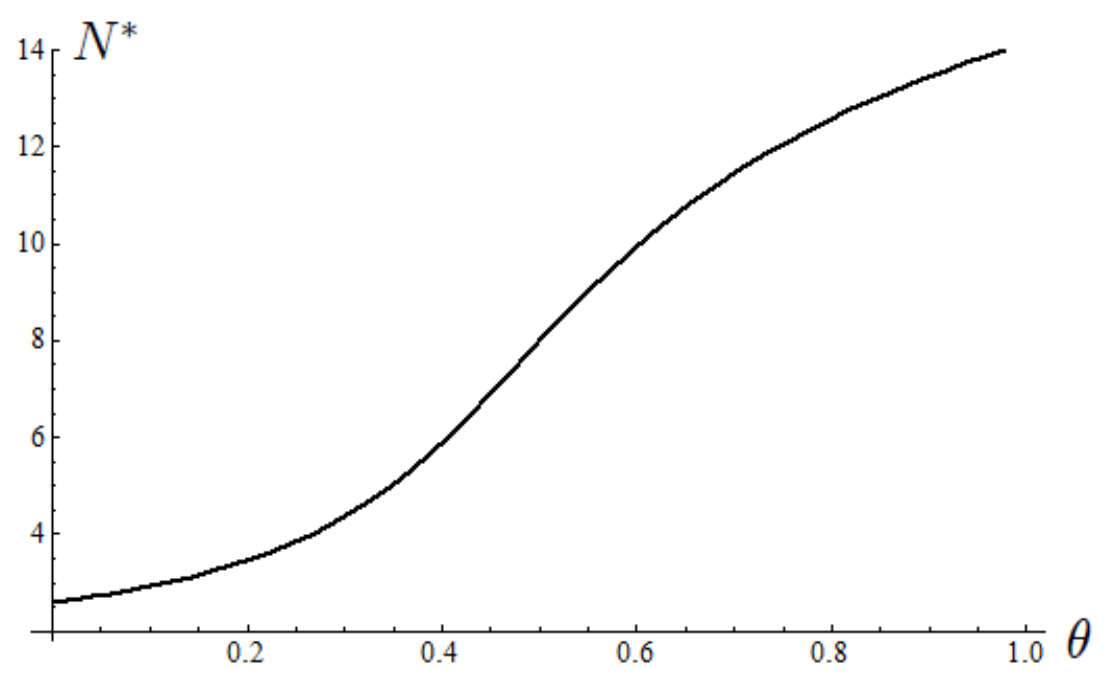

Figure 6. Equilibrium number of firms $\mathrm{N}^{*}$, as a function of spillover $\theta$

$$
\left(S=100, \beta=2, F_{0}=0.5\right)
$$

\subsection{Derivation of the limit of number of firms $N^{*}$ when mar- ket size $S$ goes to infinity}

Assuming $\beta=2, F_{0}=0.5$, we obtain a zero profit condition of the following form:

$$
\frac{0.5}{S}=\frac{N(1+(N-1) \theta)-(N-1)^{2}(1-\theta)}{N^{3}(1+(N-1) \theta)}
$$

Now, if $S \rightarrow \infty$, the left hand side of the expression above decreases to zero. Then, the right hand side of the expression will be equal to zero in two cases:

(a) for $\theta \geq 0.5$, when $N \rightarrow \infty$. Denominator of the right hand side expression 
is a polynomial of degree four (always positive), and numerator is a positive polynomial (for $\theta \geq 0.5$ ) of degree two. Therefore, as $S \rightarrow \infty$ and $\frac{0.5}{S} \rightarrow 0^{+}$, and right hand side expression approaches zero if $N \rightarrow \infty$.

(b) for $\theta<0.5$, there is a finite value of $N$, for which the above right hand side expression approaches zero. We demonstrate this with the following observation. The numerator of the right hand side expression is a negative polynomial of degree two (for $\theta<0.5$ ). At $N=1$, the derivative of the numerator is positive. Therefore, this polynomial is representing an increasing (at $N=1$ ) inverse parabola, which reaches its maximum at $N>1$, then decreases and crosses horizontal axes at $N>1$. The numerator is divided by a positive polynomial of degree four, which guarantees that the crossing point of the right hand side expression with horizontal axes is determind by the numerator. Solving $N(1+$ $(N-1) \theta)-(N-1)^{2}(1-\theta)=0$ provides the bound to the solution of (14) as $S \rightarrow \infty$.

The argument is visually illustrated in the Figure below. As the size of the market $S$ becomes very high (reaches infinity), for spillover values $\theta<0.5$, the equilibrium number of firms in the market $N^{*}$ remains finite. However, as spillovers become high $(\theta \geq 0.5)$, the equilibrium number of firms explodes for the high size of the market $S$. 


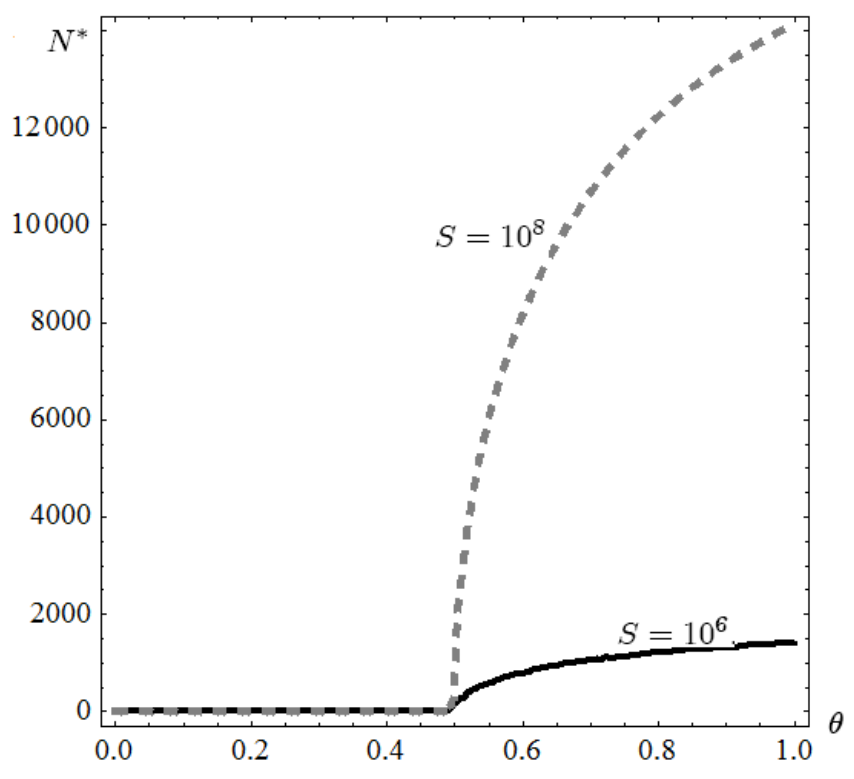

Figure 7. Value for $N^{*}$ for different $\theta$, as $S \rightarrow \infty$ (lower bound on concentration)

For more general case $\left(F_{0}=0.5\right.$, letting $\beta$ to change), zero profit condition is:

$$
\frac{0.5}{S}=\frac{N(1+(N-1) \theta)-(2 / \beta)(N-1)^{2}(1-\theta)}{N^{3}(1+(N-1) \theta)}
$$

Now, if $S \rightarrow \infty$, the left part of the expression above decreases to zero. Then, the right part will be equal to zero in two cases:

(a) for $\theta \geq \frac{2}{2+\beta}$, when $N \rightarrow \infty$. Denominator of the right hand side expression is a polynomial of degree four (always positive), and numerator is a positive polynomial (for $\theta \geq \frac{2}{2+\beta}$ ) of degree two. Therefore, as $S \rightarrow \infty$ and $\frac{0.5}{S} \rightarrow 0^{+}$, and right hand side expression approaches zero if $N \rightarrow \infty$.

(b) for $\theta<\frac{2}{2+\beta}$, there is a finite value of $N$, for which the above right hand side expression approaches zero. We demonstrate this with the following observation. The numerator of the right hand side expression is a negative polynomial of degree two (for $\theta<\frac{2}{2+\beta}$ ). At $N=1$, the derivative of the numerator is positive. Therefore, this polynomial represents an increasing (at $N=1$ ) inverse parabola, which reaches its maximum at $N>1$, then decreases and crosses horizontal axes 
at $N>1$. The numerator is divided by a positive polynomial of degree four, which guarantees that the crossing point of the right hand side expression with horizontal axes is determind by the numerator. Solving $N(1+(N-1) \theta)-$ $(2 / \beta)(N-1)^{2}(1-\theta)=0$ provides the bound to the solution of $(15)$ as $S \rightarrow \infty$.

Thus, we conclude that with $S \rightarrow \infty$, the limit of $N^{*}$ always approaches a finite number as long as $\theta<\frac{2}{2+\beta}$. For $\theta \geq \frac{2}{2+\beta}$, if $S \rightarrow \infty$, then it has to be that $N^{*} \rightarrow \infty$ also, in order for the zero profit condition to be satisfied.

The argument is visually illustrated in the Figure 8 below. As the size of the market $S$ becomes very high (reaches infinity), for spillover values $\theta<\frac{2}{2+\beta}$, the equilibrium number of firms in the market $N^{*}$ remains finite. However, as spillovers become high $\left(\theta \geq \frac{2}{2+\beta}\right)$, the equilibrium number of firms explodes with the high size of the market $S$. Also, the point where the equilibrium number of firms explodes depends on $\beta$ : if $\beta$ is high, the concentration bound disappears for much lower spillover values - markets become fragmented even if spillovers are not very high. This is not a surprising result, because if $R \& D$ investment is not very effective in raising quality ( $\beta$ is high), firms do not invest much in the $\mathrm{R} \& \mathrm{D}$, and even small knowledge spillovers will decrease R\&D enough to permit the extensive entry of firms.

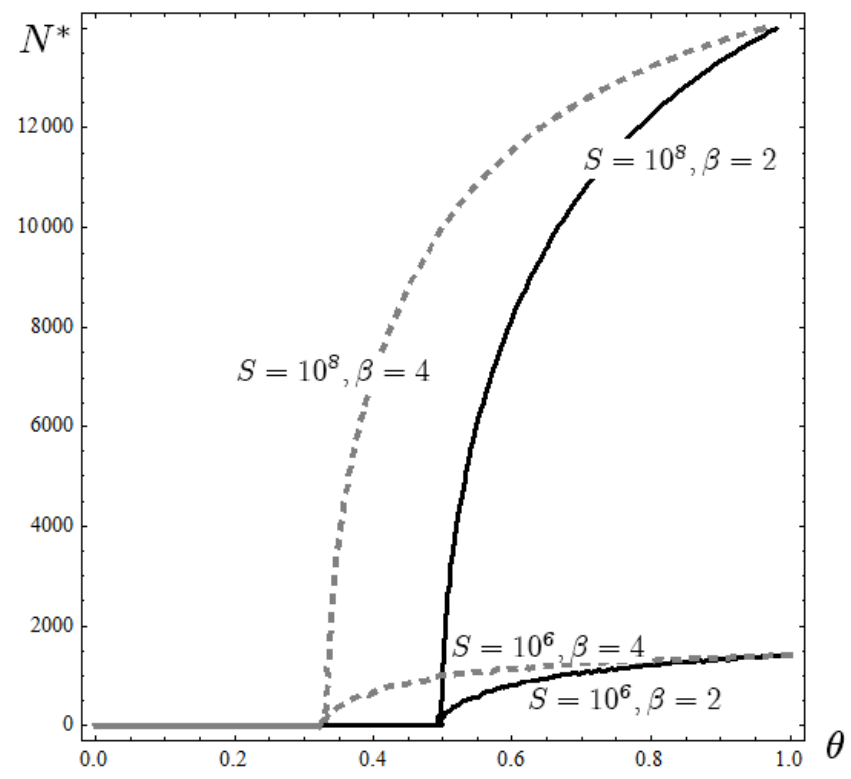

Figure 8. Value for $N^{*}$ for different $\theta$ and $\beta$, as $S \rightarrow \infty$ (lower bound on concentration) 


\subsection{Second Order Condition}

Consider the expressions for the FOC from (5), (6) and (7) - before we introduced the symmetry assumption. To find the SOC we need to differentiate:

$$
\frac{d^{2}\left(\Pi_{i}-F_{i}\right)}{d u_{i}^{2}}=\left(\frac{\partial \Pi_{i}}{\partial u_{i}^{*}} \times 1+(N-1) \frac{\partial \Pi_{i}}{\partial u_{j}^{*}} \times \theta-\beta u_{i}^{\beta-1}\right)_{u_{i}}^{\prime} . \text { After we calculate this }
$$

derivative, we the impose symmetry assumption, and substitute for $u^{\beta}=\frac{2 S(N-1)^{2}(1-\theta)}{N^{3} \beta(1+(N-1) \theta)}$ (evaluate the derivative at optimum), we obtain:

$$
\frac{d^{2}\left(\Pi_{i}-F_{i}\right)}{d u_{i}^{2}}=\frac{-(N-1)^{2}(1-\theta)(-3(1-\theta)+N(4-N+2 S(\beta-1)+(N-2+2(\beta-1)(N-1) S) \theta))}{N^{4}(1+\theta(N-1))^{2} u^{2}}<0
$$

To see whether it is true, consider the term

$$
[-3(1-\theta)+N(4-N+2 S(\beta-1)+(N-2+2(\beta-1)(N-1) S) \theta)]=G(N, \theta, \beta)
$$

in the brackets of the numerator. With the single assumption that $N \geq 2$, it is possible to show that this term is always non-negative.

$G(N, \theta, \beta)$ is increasing function of $\theta$ (for $N \geq 2$ and $\beta \geq 1$ ). In order to show that $G(N, \theta, \beta)$ is always non-negative, assume that $\theta=0$, and if $G(N, \theta=0, \beta)>$ 0 , then for any $\theta \geq 0$ it holds that $G(N, \theta, \beta)>0$. For $\theta=0, G(N, \theta, \beta)=$ $\left[-3+N(4-N+2 S(\beta-1)]=-3-N^{2}+N(4+2 S(\beta-1))\right.$. This is a negative quadratic parabola in $N$, which crosses horizontal axis only for $N>0$. Therefore, $G(N, \theta, \beta)=[-3+N(4-N+2 S(\beta-1)]$ could be negative if $N$ is very high.

However, $N$ is determined by the equilibrium condition ( $N$ is endogenous in our model $)$. We have to evaluate the value of the derivative $\frac{d^{2}\left(\Pi_{i}-F_{i}\right)}{d u_{i}^{2}}$ at the optimum, where $N=N^{*}$, which is determined by the condition (10). We know that $N^{*}$ is an increasing function of $S$ and $\theta$. Therefore, the optimal number of firms $N^{*}$ ( for $\theta=1)=\sqrt{S / F_{0}}($ from $(10))$ constitutes the upper bound on the number of firms $N^{*}$ as a function of $S$. Therefore, for any $\theta \in[0,1]$, it holds that $N^{*}\left(S, F_{0}\right) \leq \sqrt{S / F_{0}}$.

Let's take the highest value for $N^{*}$, that is $N^{*}=\sqrt{S / F_{0}}$, and evaluate $G(N, \theta, \beta)$ : 


$$
\begin{gathered}
G\left(N^{*}=\sqrt{S / F_{0}}, \theta, \beta\right)=\left[-3+\sqrt{S / F_{0}}\left(4-\sqrt{S / F_{0}}+2 S(\beta-1)\right]=\right. \\
=-3+4 \sqrt{S / F_{0}}-S / F_{0}+2 S(\beta-1) \sqrt{S / F_{0}}
\end{gathered}
$$

And it is possible to show that the above expression is always non-negative for $S \geq F_{0}$, $\beta \geq 1$. Therefore, it proves that $G(N, \theta, \beta)$ is always non-negative, and the SOC is satisfied.

\subsection{Limit of $\frac{d F_{i}}{d S}$ as $S \rightarrow \infty$}

Condition (10) defines $N^{*}$ from the implicit function $F=F_{i}\left(N^{*}, S, F_{0}\right)-\frac{S}{N^{* 2}} \equiv 0$. Therefore, the marginal effect of an increase in the market size on the individual firm's investment into quality $F_{i}\left(N^{*}, S\right)$ (endogenous sunk costs) is:

$$
\frac{d F_{i}\left(N^{*}, S\right)}{d S}=\underbrace{\frac{\partial F_{i}\left(N^{*}, S\right)}{\partial N^{*}} \frac{d N^{*}(S)}{d S}}_{\text {"entry effect" }}+\underbrace{\frac{\partial F_{i}\left(N^{*}, S\right)}{\partial S}}_{\text {"escalation effect" }}
$$

1. The "escalation effect" (the direct effect of the market size increase on the investment into quality $\left.F_{i}\left(N^{*}, S\right)\right)$ is always positive:

$$
\frac{\partial F_{i}\left(N^{*}, S\right)}{\partial S}=\frac{2(1-\theta)\left(N^{*}-1\right)^{2}}{\beta N^{* 3}\left(1+\theta\left(N^{*}-1\right)\right)}>0
$$

2. The "entry effect" (the effect of the market size increase on the investment into quality $F_{i}\left(N^{*}, S\right)$ through the change in the equilibrium number of firms $\left.N^{*}\right)$ is $\frac{\partial F_{i}\left(N^{*}, S\right)}{\partial N^{*}} \frac{d N^{*}(S)}{d S}$.

As the number of firms increases, each firm has typically fewer incentives to invest into quality. In our setup this is also the case unless spillovers are zero or rather small. That is:

$$
\frac{\partial F_{i}\left(N^{*}, S\right)}{\partial N^{*}}=\frac{-2 S\left(N^{*}-1\right)(1-\theta)\left(N^{*}-3+\left(N^{*}-1\right)\left(2 N^{*}-3\right) \theta\right)}{\beta N^{* 4}\left(1+\theta\left(N^{*}-1\right)\right)^{2}}<0 \text { for } \theta>
$$

$\theta_{c}$, where $\theta_{c}=\frac{3-N^{*}}{\left(N^{*}-1\right)\left(2 N^{*}-3\right)}$.

Vives, 2008 assigns the general ambiguity of the sign of $\frac{\partial F_{i}\left(N^{*}, S\right)}{\partial N^{*}}$ to the two opposing effects: i) the direct demand (or size) effect, and ii) the indirect (or elasticity) 
price pressure effects. The direct demand effect predicts that, for a given market size, if more firms enter, the residual demand of a firm will decline, and a firm has less incentives to invest in $\mathrm{R} \& \mathrm{D}$. The elasticity of residual demand however will increase, and this will have positive effect of the R\&D incentives because with higher elasticity of demand (that a firm faces) it is optimal for a firm to expand output and that, in turn, makes the investment in R\&D more attractive. The latter describes the second, indirect price pressure (elasticity) effect. Note that the direct demand effect typically dominates the price pressure effect, and $R \& D$ decreases with the number of firms. However, as we have just seen, it is possible that under certain circumstances (zero or very small spillovers in our case) it is the other way around (see Vives, 2008 for a comprehensive discussion on this point).

Further, as the market size increases, the equilibrium number of firms increases. From the implicit function theorem:

$$
\begin{aligned}
& \frac{d N^{*}(S)}{d S}=-\frac{\partial F\left(N^{*}, S\right) / \partial S}{\partial F\left(N^{*}, S\right) / \partial N^{*}}=-\frac{\frac{\partial F_{i}\left(N^{*}, S\right)}{\partial S}-\frac{1}{N^{* 2}}}{\frac{\partial F_{i}\left(N^{*}, S\right)}{\partial N^{*}}+\frac{2 S}{N^{* 3}}}>0 ; \\
& \quad \partial F\left(N^{*}, S\right) / \partial S=\frac{\partial F_{i}\left(N^{*}, S\right)}{\partial S}-\frac{1}{N^{* 2}}<0 ; \partial F\left(N^{*}, S\right) / \partial N^{*}=\frac{\partial F_{i}\left(N^{*}, S\right)}{\partial N^{*}}+\frac{2 S}{N^{* 3}}> \\
& 0 ; \text { and } \frac{d N^{*}(S)}{d S}>0
\end{aligned}
$$

Therefore, the "entry effect" is negative: $\frac{\partial F_{i}\left(N^{*}, S\right)}{\partial N^{*}} \frac{d N^{*}(S)}{d S}<0$

In total, $\frac{d F_{i}\left(N^{*}, S\right)}{d S}>0$, because the "escalation effect" is always higher than the "entry effect".

Now, let us consider what happens to the "escalation effect" and "entry effect" at the limit of $S$. Unfortunately, it is not possible to derive the limits analytically. Therefore, we have computed the values of the above derivatives for specific (increasing) values of $S$ (other parameter values are $F_{0}=0.5, \beta=2$ ), so that it is possible to see how the derivatives change with $S$.

From the table below, as the market size increases to infinity $(S \rightarrow \infty), \frac{d N^{*}(S)}{d S}$ approaches zero for any value of the parameter $\theta$, that is $\lim _{S \rightarrow \infty} \frac{d N^{*}(S)}{d S}=0$. Therefore, $\lim _{S \rightarrow \infty} \frac{\partial F_{i}\left(N^{*}, S\right)}{\partial N^{*}} \frac{d N^{*}(S)}{d S}=0$, which means that with the market size increasing, the 
"entry effect" vanishes.

However, the limit of the "escalation effect" depends on the value of parameter $\theta$. For low knowledge spillovers $\theta$ the "escalation effect" $\frac{\partial F_{i}\left(N^{*}, S\right)}{\partial S}$ does not approach zero, and remains above zero for increasing $S$. However, for high knowledge spillovers the limit of the direct effect of the market size on R\&D investment is $\lim _{S \rightarrow \infty} \frac{\partial F_{i}\left(N^{*}, S\right)}{\partial S}=0$. 


$$
\frac{\partial F_{i}\left(N^{*}, S\right)}{\partial S} \quad \frac{\partial F_{i}\left(N^{*}, S\right)}{\partial N^{*}} \quad \frac{d N^{*}(S)}{d S} \quad \frac{d F_{i}\left(N^{*}, S\right)}{d S}
$$

$\begin{array}{rlrrrr}\theta=0.1 & S=10^{2} & 0.1117 & -0.79177 & 6.9 \times 10^{-4} & 0.1111 \\ & S=10^{4} & 0.1111 & -92.4616 & 7.7 \times 10^{-8} & 0.1111 \\ & S=10^{6} & 0.1111 & -9258.43 & 4.88 \times 10^{-11} & 0.1111 \\ & S=10^{8} & 0.1115 & -831246 & 5.09 \times 10^{-10} & 0.1111 \\ \theta=0.2 \quad S=10^{2} & 0.0782 & -1.47 & 1.5 \times 10^{-3} & 0.07599 \\ & S=10^{4} & 0.7858 & -149 & 1.86 \times 10^{-9} & 0.07579 \\ & S=10^{6} & 0.0757 & -14939 & 1.71 \times 10^{-13} & 0.07570 \\ & S=10^{8} & 0.0753 & -149480 & 3.22 \times 10^{-14} & 0.0753 \\ \theta=0.4 \quad S=10^{2} & 0.02366 & -0.5566 & 1.2 \times 10^{-2} & \\ & S=10^{4} & 0.01354 & -25 & 7 \times 10^{-7} & 0.01698 \\ & S=10^{6} & 0.01335 & -2455 & 8 \times 10^{-12} & 0.01353 \\ & S=10^{8} & 0.01335 & -245540 & 1.32 \times 10^{-14} & 0.01335 \\ & & & & & 0.01335\end{array}$

$\begin{array}{rrrrrr}\theta=0.5 & S=10^{2} & 0.0106 & -0.2134 & 0.028 & 4.625 \times 10^{-3} \\ S & =10^{4} & 0.00061 & -0.306 & 0.001 & 3.04 \times 10^{-4} \\ S & =10^{6} & 2.9 \times 10^{-5} & -0.32 & 6 \times 10^{-5} & 9.8 \times 10^{-7} \\ S & =10^{8} & 1.4 \times 10^{-7} & -0.33 & 2.8 \times 10^{-7} & 4.7 \times 10^{-8}\end{array}$

$\begin{array}{rrrrrr}\theta=0.7 & S=10^{2} & 2.62 \times 10^{-3} & -0.04 & 5.4 \times 10^{-2} & 4.6 \times 10^{-5} \\ S=10^{4} & 3.6 \times 10^{-5} & -0.0066 & 5.3 \times 10^{-3} & 1.023 \times 10^{-7} \\ S=10^{6} & 3.7 \times 10^{-8} & -0.0007 & 5.3 \times 10^{-4} & 3.8 \times 10^{-8} \\ S=10^{8} & 3.7 \times 10^{-12} & -0.00007 & 5.3 \times 10^{-5} & 3.7 \times 10^{-12}\end{array}$

\begin{tabular}{|c|c|c|c|c|}
\hline$\theta=1$ & $S=10^{2}$ & 0 & 0 & 0.07 \\
\hline & $S=10^{4}$ & 0 & 0 & 0.007 \\
\hline & $S=10^{6}$ & 0 & 0 & 0.0007 \\
\hline & $S=10^{8}$ & 0 & 0 & 0.00007 \\
\hline
\end{tabular}


Therefore, we conclude that for high spillovers $\lim _{S \rightarrow \infty} \frac{d F_{i}\left(N^{*}, S\right)}{d S}=0$. As market size increases to infinity, $S$ has no effect on the R\&D investment of individual firm $\left(F_{i}\right)$, the entry barriers created by the endogenous sunk costs disappear, and the market becomes fragmented (as market size increases to infinity). However, for low spillovers $\lim _{S \rightarrow \infty} \frac{d F_{i}\left(N^{*}, S\right)}{d S}>0$. This means that as the market size increases to infinity, $S$ has a positive (non-zero) effect on the R\&D investment of an individual firm $\left(F_{i}\right)$, and the entry barriers created by the endogenous sunk costs are sustained. The market remains concentrated as the market size increases to infinity.

\subsection{Total industry investment in quality for different level of spillovers}

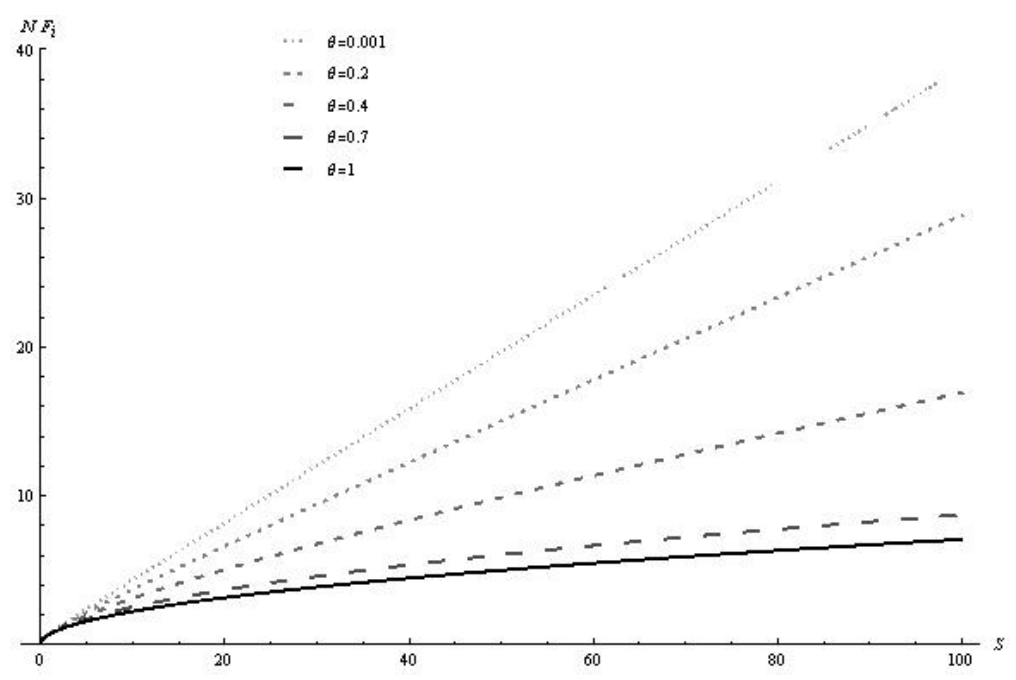

Figure 9. Total expenditures on quality and market size, for different values of $\theta$ 


\subsection{Comparative statics with respect to $\beta$ for the number of active firms in the market $N^{*}$}
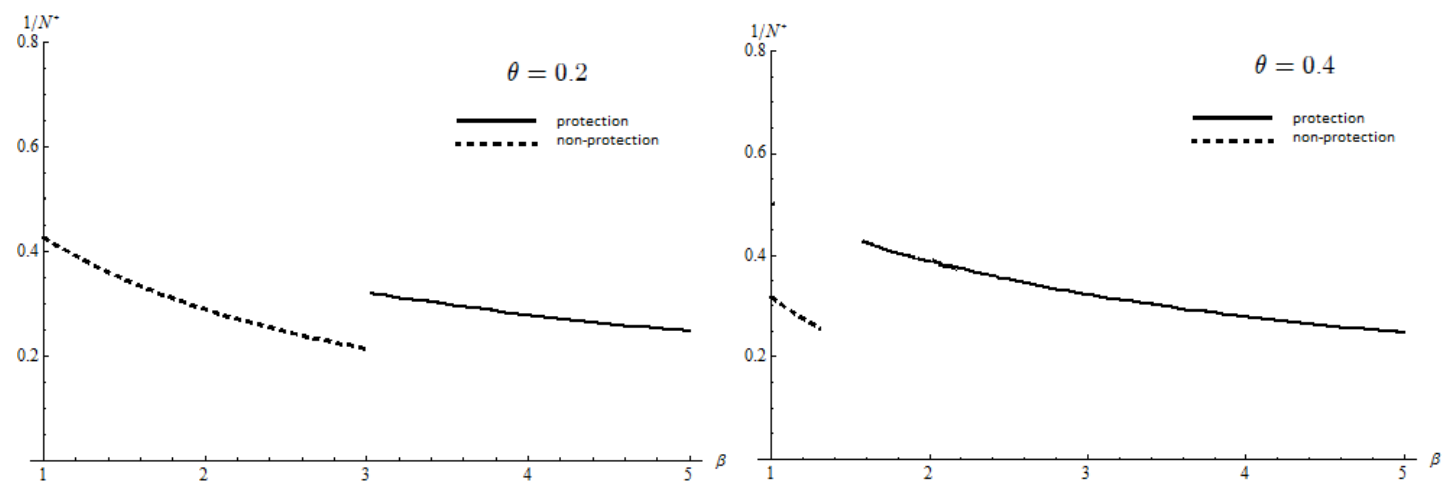

Figure 10. Equilibrium market concentration as a function of $\beta$ for ex ante $\theta=0.2$ (left) and for ex ante $\theta=0.4$ (right)

From Figure 10 above, we can split the range of $\beta$ values roughly into three parts:

(1) for low $\beta$, when the investment in $R \& D$ is more effective, industries with higher ex ante spillovers $\theta$ will have higher number of active firms in the market $N^{*}$ and lower concentration (dashed line on the Figure 10 (right) is below the dashed line on Figure 10 (left) for $\beta \leq 1.75$ );

(2) for intermediate values of $\beta$, industries with higher ex ante spillovers $\theta$ will now have a lower number of active firms in the market $N^{*}$ and the higher concentration (solid line in the Figure 10 (right) is above the dashed line in Figure 10 (left) for $\beta \in[1.75,3])$. This happens because for higher spillovers $\theta$ firms are already using protection against spillovers, which makes the investment into quality more attractive, increases endogenous sunk costs, and prevents entry;

(3) for high values of $\beta$ number of firms is the same for all values of ex ante spillovers $\theta$ (solid lines on Figure 10 (left) and (right) coincide for $\beta \geq 3$ ). This happens because for high enough $\beta$, firms find it beneficial to protect against spillovers in equilibrium. This limits effective spillovers to zero and makes equilibrium number of firms equal for all ex ante values of $\theta$. 


\section{References}

Amir, R., Evstigneev, I., and Wooders, J. 2003. "Noncooperative versus cooperative R\&D with endogenous spillover rates", Games and Economic Behavior. Volume 42, Issue 2, Pages 183-207

Atallah, G. 2004. "The Protection of Innovations," CIRANO Working Papers 2004s-02, CIRANO

Audretsch, D. and Feldman, M. 1996. "R\&D Spillovers and the Geography of Innovation and Production." American Economic Review, American Economic Association, vol. 86(3): 630-40.

Caballero, R. and Jaffe, A. 1993. "How High are the Giants' Shoulders: An Empirical Assessment of Knowledge Spillovers and Creative Destruction in a Model of Economic Growth." NBER Macroeconomics Annual 1993, Volume 8: 15-86.

Cohen, W. and Levin, R. 1989. "Empirical studies of innovation and market structure." In Handbook of Industrial Organization, ed. R. Schmalensee and R. Willig, Edition 1, Volume 2, Chapter 18: 1059-1107.

De Bondt, R. 1997. "Spillovers and innovative activities", International Journal of Industrial Organization. Volume 15, Issue 1, Pages 1-28.

Ellison, G. Glaeser, E. and Kerr, W. 2010. "What Causes Industry Agglomeration? Evidence from Coagglomeration Patterns." American Economic Review, 100(3): 1195-1213.

Gersbach, H. and Schmutzler, A. 2003. "Endogenous spillovers and incentives to innovate," Economic Theory, Springer, vol. 21(1), pages 59-79, 01.

Henderson R. and Cockburn, I. 1996. "Scale, Scope, and Spillovers: The Determinants of Research Productivity in Drug Discovery." RAND Journal of Economics, The RAND Corporation, vol. 27(1): 32-59.

Javorcik, B. S. 2004. "Does foreign direct investment increase the productivity of domestic firms? In search of spillovers through backward linkages." American Economic Review, 94(3): 605-627. 
Kamien, M., Muller, E. and Zang, I. 1992. "Research Joint Ventures and R\&D Cartels." American Economic Review, American Economic Association, vol. 82(5): 1293-306.

Levin, R., Cohen, W. and Mowery, D. 1985. "R\&D Appropriability, Opportunity, and Market Structure: New Evidence on Some Schumpeterian Hypotheses." American Economic Review, American Economic Association, vol. 75(2), pages 20-24.

Mesquita, L. F., Anand, J. and Brush, T. H. 2008. "Comparing the resource-based and relational views: knowledge transfer and spillover in vertical alliances". Strategic Management Journal, 29: 913-941.

Poyago-Theotoky, J. 1999. "A Note on Endogenous Spillovers in a Non-Tournament R \& D Duopoly." Review of Industrial Organization. Volume 15, Issue 3, pp 253-262.

Scotchmer, S. 2004. Innovation and Incentives. Cambridge, MA: MIT Press.

Shenkar, O. 2010. Copycats: How Smart Companies Use Imitation to Gain a Strategic Edge. Harvard Business Press

Spence, A. M. 1984. "Cost Reduction, Competition, and Industry Performance." Econometrica, 52: 101-21.

Střelický, J. and Žigić, K. 2011. "Intellectual Property Rights Protection and Enforcement in a Software Duopoly." CERGE-EI Working Paper Series No. 435.

Sutton, J. 1991. Sunk Costs and Market Structure: Price Competition, Advertising and the Evolution of Concentration. Cambridge, MA: MIT Press.

Sutton, J. 1998. Technology and Market Structure. MIT Press.

Sutton, J. 2007. "Market Structure: Theory and Evidence." In Handbook of Industrial Organization, ed. Armstrong, M. and Porter. R., Vol 3: 2301-2368.

Tesoriere, A. 2008. "A Further Note on Endogenous Spillovers in a Non-tournament R\&D Duopoly," Review of Industrial Organization, Springer, vol. 33(2), pages 177184.

Vives, X. 2008. "Innovation and Competitive Pressure." The Journal of Industrial Economics, 56: 419-469. 
Zabojnik, J. 2002. "A Theory of Trade Secrets in Firms", International Economic Review, Vol. 43, No. 3, pp. 831-855. 


\section{Working Paper Series}

ISSN 1211-3298

Registration No. (Ministry of Culture): E 19443

Individual researchers, as well as the on-line and printed versions of the CERGE-EI Working Papers (including their dissemination) were supported from institutional support RVO 67985998 from Economics Institute of the ASCR, v. v. i.

Specific research support and/or other grants the researchers/publications benefited from are acknowledged at the beginning of the Paper.

(c) Olena Senyuta and Krešimir Žigić, 2012

All rights reserved. No part of this publication may be reproduced, stored in a retrieval system or transmitted in any form or by any means, electronic, mechanical or photocopying, recording, or otherwise without the prior permission of the publisher.

Published by

Charles University in Prague, Center for Economic Research and Graduate Education (CERGE) and

Economics Institute ASCR, v. v. i. (EI)

CERGE-EI, Politických vězňů 7, 11121 Prague 1, tel.: +420 224005 153, Czech Republic.

Printed by CERGE-EI, Prague

Subscription: CERGE-EI homepage: http://www.cerge-ei.cz

Phone: + 420224005153

Email: office@cerge-ei.cz

Web: http://www.cerge-ei.cz

Editor: Michal Kejak

The paper is available online at http://www.cerge-ei.cz/publications/working_papers/.

ISBN 978-80-7343-276-8 (Univerzita Karlova. Centrum pro ekonomický výzkum a doktorské studium)

ISBN 978-80-7344-268-2 (Národohospodářský ústav AV ČR, v. v. i.) 
CERGE-EI

P.O.BOX 882

Politických vězňů 7

11121 Praha 1

Czech Republic http://www.cerge-ei.cz 